DOE/OR/01-1313\&D2

Design/Installation and Structural Integrity Assessment of Bethel Valley Low-Level Waste Collection and Transfer System Upgrade for Building 3092 (Central Off-Gas Scrubber Facility) at Oak Ridge National Laboratory

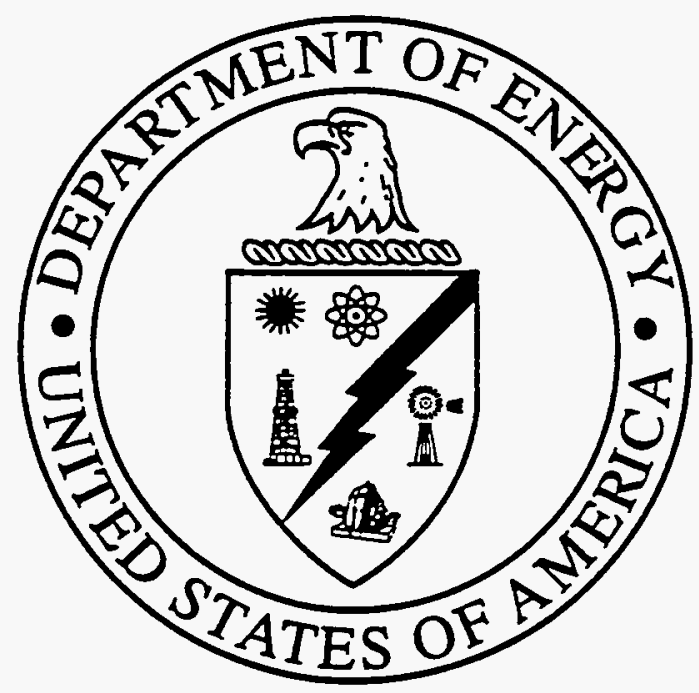




\section{Gilbert/Commonwealth, Inc.}

contributed to the preparation of this document and should not be considered an eligible contractor for its review.

This report has been reproduced directly from the best available copy.

Available to DOE and DOE contractors from the Office of Scientific and Technical Information, P.O. Box 62, Oak Ridge, TN 37831; prices availabie from 615-576-8401 (fax 615-576-2865).

Available to the public from the National Technical Information Service, U.S. Department of Commerce, 5285 Port Royal Rd., Springfield, VA 22161. 
Energy Systems Environmental Restoration Program ORNL Environmental Restoration Program

\title{
Design/Installation and Structural Integrity Assessment of Bethel Valley Low-Level Waste Collection and Transfer System Upgrade for Building 3092 (Central Off-Gas Scrubber Facility) at Oak Ridge National Laboratory
}

Date Issued-January 1995

\author{
Prepared by \\ Gilbert/Commonwealth, Inc. \\ Oak Ridge, Tennessee \\ under subcontract 32X-GJF75C
}

Prepared for U.S. Department of Energy

Office of Environmental Restoration and Waste Management under budget and reporting code EW 20

Environmental Restoration and Waste Management Programs

Oak Ridge National Laboratory

Oak Ridge, Tennessee 37831-6285 managed by

MARTIN MARIETTA ENERGY SYSTEMS, INC.

for the

U.S. DEPARTMENT OF ENERGY under contract DE-AC05-84OR21400 


\section{DISCLAIMER}

This report was prepared as an account of work sponsored by an agency of the United States Government. Neither the United States Government nor any agency thereof, nor any of their employees, make any warranty, express or implied, or assumes any legal liability or responsibility for the accuracy, completeness, or usefulness of any information, apparatus, product, or process disclosed, or represents that its use would not infringe privately owned rights. Reference herein to any specific commercial product, process, or service by trade name, trademark, manufacturer, or otherwise does not necessarily constitute or imply its

endorsement, recommendation, or favoring by the United States Government or any agency thereof. The views and opinions of authors expressed herein do not necessarily state or reflect those of the United States Government or any agency thereof. 


\section{DISCLAIMER}

Portions of this document may be illegible in electronic image products. Images are produced from the best available original document. 
This document describes and assesses planned modifications to be made to the Building 3092 Central Off-Gas Scrubber Facility of the Oak Ridge National Laboratory, Oak Ridge, Tennessee. The modifications are made in response to the requirements of 40CFR264 Subpart J, relating to environmental protection requirements for buried tank systems.

The modifications include the provision of a new scrubber recirculation tank in a new, below ground, lined concrete vault, replacing an existing recirculation sump that does not provide double containment. A new buried, double contained pipeline is provided to permit discharge of spent scrubber recirculation fluid to the Central Waste Collection Header. The new vault, tank, and discharge line are provided with leak detection and provisions to remove accumulated liquid. New scrubber recirculation pumps, piping, and accessories are also provided.

This assessment concludes that the planned modifications cornply with applicable requirements of 40CFR264 Subpart J, as set forth in Appendix $F$ to the Federal Facility Agreement, Docket No. 89-04-FF, covering the Oak Ridge Reservation.

A formal desıgn certification statement is included herein on Page 53. a certification coverıng the installation shall be executed prior to placing the modified facility into service.

Certified by: Harvey N. Goldstein, P.E.

Directive Engıneer

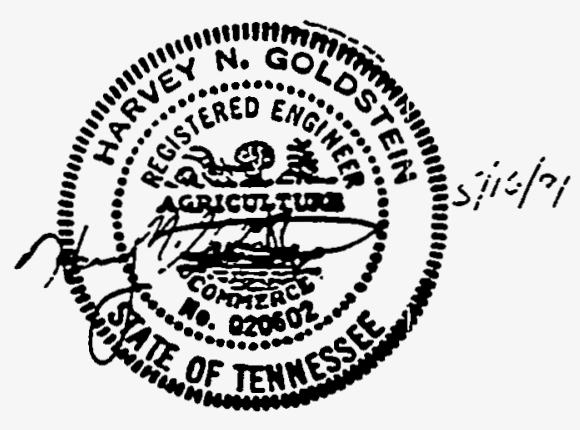


I. Introduction 1

II. Description of Project 2

III. Purpose of Project 4

IV. Assessment Results 6

A. Introduction 6

8. Standards for Designilnstallation of New or Replacement Tank Systems

1. Design Installation Assessment

(a) Design Standards il

(b) Hazardous Substance Characteristics 27

(c) Corrosion Protection 30

(d) Vehicular Traffic Protection 33

(e) Desıgn Consıderations 34

2. Tank Systems Installation 37

3. Inspection Reports 44

4. Backfilling 46

5. Testing. 49

6. Ancillary Equipment Protection 49

7. Corrosion Protection 51

8. Corrosion Expert 51

9. Documentation 52 


\section{TABLE OF CONIENTS}

Page

C. Standards for Containment/Release Detection 55

1. Secondary Containment Systems Requirements 55

(a) Construction Compatibility 55

(b) Containment Systems Foundation 57

(c) Leak Detection System 58

(d) Drainage and Liquid Removal 59

(e) Secondary Containment for Tanks 60

(f) Additional Requirements 61

$\begin{array}{lll}\text { V. Conclusions } & 68\end{array}$

Appendix A: Central Off-Gas Scrubber Facility-Building 3092 
This document presents a Designilnstallation and Structural Integrity Assessment for a replacement tank system for portions of the Bethel Valley Low Level Waste (LLW) System, located at the Oak Ridge Reservation, Oak Ridge, Tennessee. This issue of the assessment covers the design asoects of the replacement tank system, and certifies that the design has sufficient structural integrity and is acceptable for the storing or treating of hazardous and!or radioactive substances.

This document will be reissued at a future date and will then include the assessment of the installation of the replacement tank system. The present issue identifies specific activities that must be completed during the fabrication, installation, and testing of the replacement tank system in order to provide assurance that the final installation complies with governıng requirements. These requirements are based on meeting the intent of 40CFR264 Subpart J -Tank Systems, as set forth in Appendix F to the Fedieral Facility Agreement, Docket No. 89-04-FF, covering the Dak Ridge Reservation.

The assessment presented in this document is responsive to the Environmental Restoration Agreement for the Oak Ridge Reservation. The format utilized in preparation of the document follows the format presented in Appendix F. Low Level Radioactive Waste Tank Systems, appended to the Agreement. 


\section{DESCRIPTION OF PROJECT}

The LLW system at Oak Ridge National Laboratory (ORNL) consists of facilities to collect, transfer, concentrate, and store aqueous radioactive waste solutions from various sources at the Laboratory. The system is designed to accommodate waste solutions having an activity content as high as 5 cigal The coilection and transfer system consists of an extensive network of underground piping, valve boxes, and collection tanks it allows for collection of LLW from the various source facilities and periodic transier througn the Central Waste Collection Header (CWCH) to the storage tanks serving the Laboratory's central LLW evaporator. Status of various system operations is centrally monitored at the Laboratory's Waste Operations Control Center (WOCC). Wastes are concentrated at the evaporator, and the concentrate is collected in a local storage tank and periodically transferred to tanks located in the Melton Valley area of the Laboratory for ultimate storage.

The Exhibit II-1 presents a map of a portion of the Bethel Valley complex, showing all of the facilities, existing and new, that comprise the entire scope of the Bethel Valley LLW Upgrade Project. This assessment report pertains to the modifications to be made to the existing Central Off-Gas Scrubber Facility (Building 3092) to achieve compliance with the Federal Facility Agreement This includes the provision of a new scrubber recirculation tank to contain. store, and treat (adjust $\mathrm{pH}$ ) scrubber sorbent liquid. The scrubber recirculation tank contains process fluid, and is not a waste tank, per se Due to the nature of the tank contents, the tank is designed, fabricated, installed, and inspected in a manner consistent with the requirements that would apply to a LLW tank. to the extent feasible. The tank contents are treated as LLW upon jetting from the tank into the discharge line to the $\mathrm{CWCH}$. The discharge line is classified as a LLW line. A more detailed description of the modifications to this facility are described in Sections III and IV of this assessment.

The limits of the probable maximum flood due to extreme flood stage for White Oak Creek, is superimoosed on the map. As may be noted, site flooding from this type of phenomena is not a credible event for the Building 3092 portion of the upgrade. 


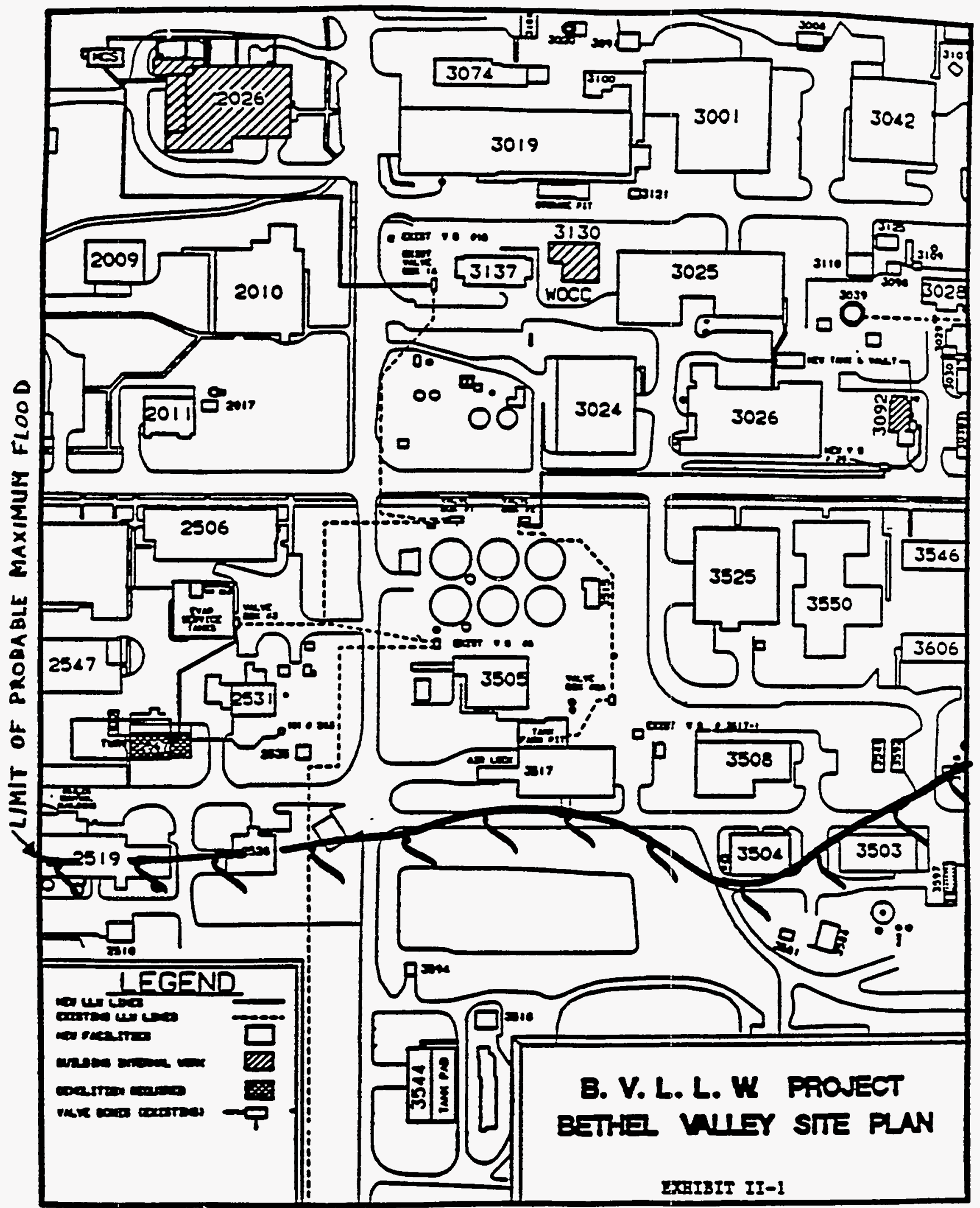


Portions of the LLW system are several decades old, or older, and do not comply with current environmental protection regulations. Several subsystems of the LLW system have been designated to receive a state-of-the-art reolacement and refurbishment. One such subsystem serves Building 3092, the Central Off-Gas Scrubber Facility. This assessment focuses on the scope of work for the Building 3092 replacement LLW Collection and Transfer System, which is comprised of the following.

- Provision of a new $3000 \mathrm{gal}$. stainless steel tank withın a new lined concrete vault, below grade, replacing the adjacent existing scrubber sump which is abandoned in place. The existing reinforced concrete sump vault does not have provisions for secondary containment. The new vault provides secondary containment for the new tank, and includes a low point sump with leak detection instrumentation, and steam jet ejectors for removal of accumulated liquid. The new tank serves as a collection reservoir for process fluid returning from the scrubber equipment, and is not a waste tank.

- Provision of new motor driven and steam turbine driven scrubber recirculation pumps and sufficient new piping to integrate the new pumps and tank with the existing scrubber equipment.

- Provisions to add caustic to the contents of the new tank, to adjust pH for optımum scrubbing performance, and to minimize the potential for corrosion of the new tank, pumps, and piping.

- Steam jet ejectors, buried double wall transfer pıping, and a new valve box. No. 2B. The transfer piping is routed from the new scrubber tank to valve box No. 2B, and thence onward to valve box No. 2 for tie-in to the Central Waste Collection Header. 
- For the purpose of this assessment, the following terms are defined.

- Tank is defined as the new scrubber recirculation tank provided in the new tank vault; this term is limited to the tank proper and excludes the tank vault, liners, and other design features.

- Tank System is defined as the entire fluid retaınıng system for scrubber sorbent fluid from the tie-in points with the existing scrubber return piping to the new tank and vault, the new recirculating pumps, and the pump discharge lines to the tie-in io the existing scrubber feed line. In addition, the system includes the transfer line from the new tank and vault to the tie-In to the CWCH at existing valve box No. 2. A new intermediate valve box, No. 2B, is also included.

- Primary Fluid Boundary is defined as piping contaınıng either the scrubber sorbent fluid or the LLW, including single wall pipıng within buildings, the inner pipe in double wall pipe runs, and the new tank.

- Secondary Contaınment is defined as the outer pipe in double wall pipe runs and the reinforced concrete tank vault, with inner staınless steel liner.

- Support Equipment is defined as, but not necessarily limited to, equipment required for system functional capability, such as sump level instrumentation, steam jet ejectors and associated piping and valves, and the scrubber recirculating pumps. 


\section{ASSESSMENT RESULTS}

A. Introduction

This assessment covers the LLW Collection, and Transfer System designed for installation to serve Building 3092, the Central Off-Gas Scrubber Facility, and the new transfer lines connecting Building 3092 with new valve box No. $2 B$ and the Central Waste Collection Header ( $\mathrm{CWCH}$ ) at existing valve box No. 2 .

This assessment reviews the design of the replacement Tank System for the above described Building 3092 facility (Section IV.B). The assessment also covers the secondary containment provisions and ancillary equipment associated with the Building 3092 facility (Section IV C). Simplified diagrams Illustrating the schematic and physical aspects of $:$ is subsystem are shown in Exhibits IV-1, IV-2, and IV-3.

Several design conditions are presented for evaluation, as follows:

- Single wall pipe routed within the facility, where the pipe is visiole for routine (i.e., daily) visual inspection to detect leakage. Potential leakage from flanged connections, valve stems, and pump seais is limited to small amounts of fluid that would be detected by routine observations. This condition is manifested in limited portions of the existing Building 3092 facility where tie-ins are made to the scrubber feed and recirculation (drain) systems. The condition also exists for the recirculation piping above the top slab of the new tank vault. A major spill from the single wall piping is considered extremely unlikely, due to the stringent design measures taken for this facility. These include high grade, corrosion resistant materials. and design to a high hazard classification, with seismic and other loads evaluated.

-

Single wall pipe routed within a vaulted structure, where the piping is not visible for routıne visual inspection. Potential leakage wouid be contained and detected by the retention and leak detection 


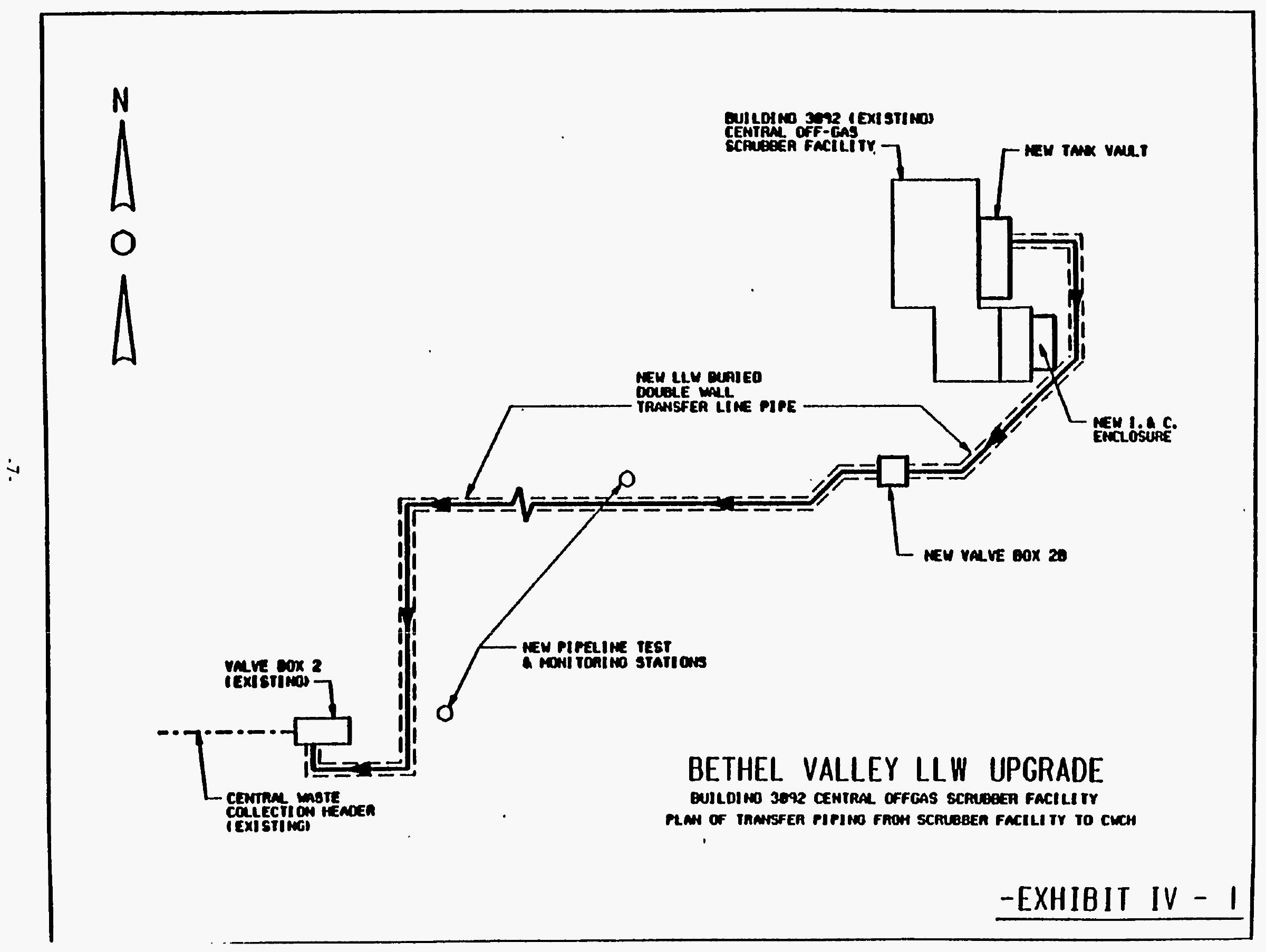




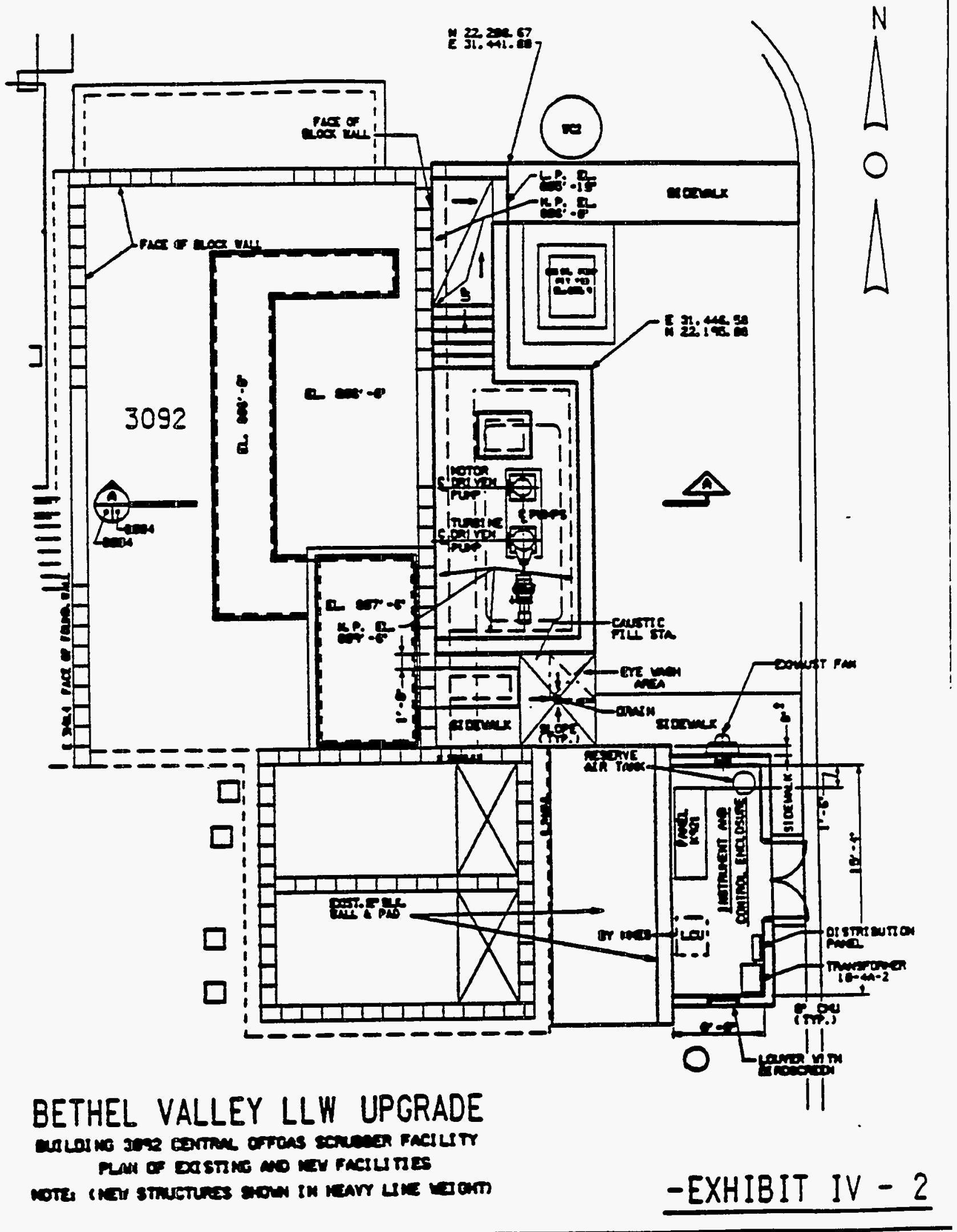

8 


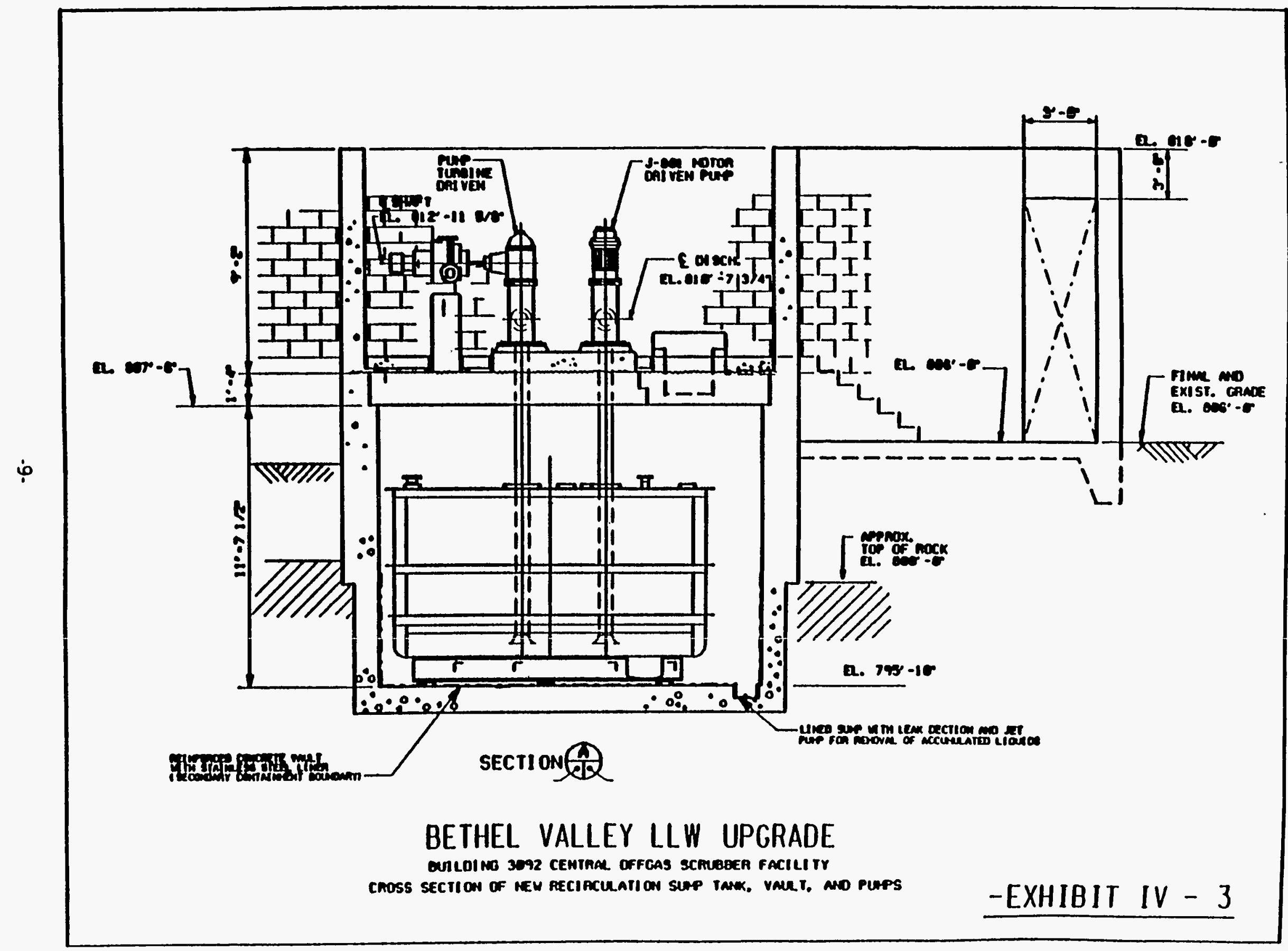


capabilities of the stainless steel lined vault (described in IV.C of this assessment).

- Double wall pipe embedded in concrete or buried underground The outer pipe fulfills the secondary containment function and is protected from corrosion by an exterior coating in conjunction with a galvanic anode type cathodic protection system. The annular space between the double wall pipe retains potential leakage from the inner, primary. waste contaınıng pipe. The space is provided with leak detection by pressurization with nitrogen and monitoring of the annuiar space pressure The annular space is divided into many discrete segments and provided with test and monitoring stations to facilitate location and repair of potential leaks.

The buried piping runs are classified as Transfer piping, and convey spent scrubber sorbent in ba:ches from the new tank to the CWCH for disposal

- A tank comprising a single wall process fluid holding and collection tank fabricated from corrosion resistant material and located in a below grade reinforced concrete vauls. The vault, which fulfills the secondary containmert inction, 15 provided with a stainless steel inner liner and a sump with a leak detection sysiem The vault is designed to withstand design basis natural prenomena, including seismic events and torradoes

The overall conclusion of this assessment is that the various elemerts described above, which compose the entire replacement Tank System for the Building 3092 facility, are in compliance with applicable portions of Appendix $F$ to the Federal Facility Agreement. The remaining portions of this assessment describe the means of compliance for each design feature and confirm the adequacy of the design for the purposes of environmental protection. 


\section{B. Standards for Designilnstallation of New or Replacement Tank Systems}

1. Designilnstallation Assessment

This part of the assessment focuses on the following aspects of the replacement Tank System:

- Design standards, including codes, criterıa, and specificatıons used by the design project for design, fabrication, and installation of the Tank System.

- Characteristics of hazardous substances to be contained by the Tank System.

- Corrosion protection provided by the design for metal components that will be in direct contact with the soll, such as the outer pipe in a double wall pipe system.

- Man-ındused hazards, such as vehicular traffic.

- Natural phenomena, such as seismic events, frost heave. ground water, heavy rain and surface run-off, and potential flooding of nearby water sources (White Oak Creek).

\section{(a) Design Standards}

The applicable standards, codes, and criteria used by the design project that govern the design, fabrication, and installation of the tank systems are identıfied herein. The application of standards, codes, and criteria is generally performed on an engineering disciplinary basis and. therefore, the following listing is so organized. The list has been edited to minımize duplication, but certain entries are repeated if they constitute a key element in the input for a partıcular discipline work scope. The adequacy of these 
standards, codes, and criteria is evaluated by discipline and is correlated with specific design features when applicable.

(i) Mechanical Engineering and Design

The scope of mechanical engineering and design for the replacement tank system includes the scrubber recirculation tank, all LLW containıng piping (single and double wall), and process support equipment such as the scrubber recirculation pumps and piping.

The assessment concludes that the standards, codes, criteria, and specifications for the mechanical engıneering aspects of the Tank System for the Building 3092 Central Off-Gas Scrubber Facility, are suitable and appropriate. The tank, primary and secondary pipıng, and other design elements are covered by codes, etc. that mandate use of appropriate materials, design, fabrication and installation, and examination and inspection procedures and techniques.

The selection of materials for the Tank System is appropriate in order to assure compatibility with the process solution to be stored. Building 3092 contains several thousand gallons of an aqueous solution whose pH ranges from weakly caustic to weakly acidic. The material selected for principal portions of the primary, or inner, boundary of the new piping is Type $304 \mathrm{~L}$ stainless steel, which exhibits excellent corrosion resistance in the presence of moderately weak acids and weak caustic solutions.

The scrubber recirculation tank is also constructed of Type $304 \mathrm{~L}$ austenitic stainless steel. The design of the Tank System provides for the capability to add caustic in measured amounts to adjust the pH of the tank liquid. 
Related support equipment such as steam jet ejectors, scrubber pumps, and vault and sump liners are also fabricated from Type 304L austenitic stainless steel. The Type 304L material selected is considered to be compatible with the wastes it will be exposed to

This portion of the assessment is valid for the design and installation of the Tank System. The design is essentially complete and is in compliance with the referenced codes, standards, and criteria. During the installation phase of the project, actions such as examinations, inspections, and tests must be undertaken to confirm that the installation remains in conformance with the design and with required codes, standards, etc.

The application of the following standards, codes, and criteria to essential elements of the design is indicated as follows:

P - applies to primary (inner) LLW contaınıng pipe and valves

5 - applies to secondary (outer) pipe

T. $\quad$ - applies to LLW containıng tanks

\section{Codes}

American Society of Mechanical Engıneers (ASME)

- NQA-1, Quality Assurance Program Requirements T for Nuclear Facilities

- Boiler and Pressure Vessel Code

Section II, Material Specifications 
(Governs materials specifications in conjunction with ASTM Standards)

- Section III, Nuclear Power Plant Components

Division 1, Subsection NB

(Used to govern Drocurement of piping

materiais)

- Section V, Non-destructive Examination

(Governs non-destructive examination in conjunction with Section VIII)

- Section VIII, Division 1, Pressure Vessels

(Design code for tank to the extent applicable; tank is not code stamped)

- Section IX. Welding and Brazing Qualifications (Governs qualification of welders)

American National Standards Institute (ANSI)

- B16.5, Steel Pipe Flanges and Flanged Fittings (Governs flange pressure/temperature ratıngs)

- B31.3, Chemical Plant and Petroleum Refinery $P, S$ Piping (Design code for LLW piping)

\section{Standards}

American Society for Testıng Materials (ASTM)

- A-182, Specification for Forged or Rolled Alloy-Steel Pipe Flanges, Forged Fittings, and Valves and Parts for High Temperature Service 
- A-193. Specification for Alloy-Steel and

P. S, T

Stainless Steel Bolting Materials for High

Temperature Service

- A-194. Specification for Carbon and Alloy-Steel

$P, 5, T$

Nuts for Boits for High Pressure and High

Temperature Service

- A-213. Soecification for Seamless Ferritic and

Austenitic Alloy-Steel Boller-Superheater and Heat Exchanger Tubes

- A-240, Specification for Heat-Resisting Chromium T and Chromium-Nickel Stainless Steel Plate, Sheet, and Strip for Pressure Vessels

- A-262, Practices for Detecting Susceptibility to P. T Intergrannular Attack on Austenitic Staınless Steels

- A-312. Specification for Seamless and Welded $P, S, T$ Austenitic Chromium-Nickel Alloy Steel Pipe for High Temperature Service

- A-358, Specification for Electric-Fusion-Welded Austenitic Chromium-Nickel Alloy Steel Pipe for High Temperature Service

- A-403, Specification for Wrought Austenitic P. S, T Staınless Steel Pipıng Fittıngs

- A-479. Specification for Stainless and $T$ Heat-Resısting Steel Wire, Bars, and Shapes for Use in Bollers and Other Pressure Vessels 
- D-227. Specification for Coal-Tar Saturated

Organic Felt Used in Roofing and Waterproofing

- D-450, Specification for Coal-Tar Pitch Used in

Roofing, Dampproofing, and Waterproofing

American Water Works Association

- 203-86. Coal-Tar Protective Coatıngs and Linings for Steel Water Pipelines - Enamel and Tape-Hot-Applied (Governs coatıng on secondary pipe for corrosion protection in soil)

American Welding Society

- A5.9. Specification for Corrosion Resisting $P, 5, T$ Chromium and Chromium-Nickel Steel Bare and Composite Metal Cored and Stranded Welding Electrodes and Welding Rods

- QC-1, Standard for AWS Certification of Welding P, S, T Inspectors

- SNT-TC-1A, Recommended Practice, American P. S. T Society for Non-destructive Testing, Inc.

- Occupational Safety and Health Administration $T$ Standards (OSHA)

- Uniform Buliding Code, 1988 T

- UCRL-15910, Design and Evaluation Guidelines T for DOE Facilities Subjected to Natural Phenomena Hazards

- Hydraulic Institute Standards 
The scope of structural engineering and design includes the lined, vaulted structure providing secondary containment for the new tank and new valve box No. 28 .

The new tank vault is a reinforced concrete structure designed to house the new Building 3092 scrubber sump tank and associated recirculation pumps. The interior dimensions of the vault are $16 \mathrm{ft} . \times 6 \mathrm{ft} .4 \mathrm{in}$. in plan by $11 \mathrm{ft} .7$ in. high. The vault extends downward approximately $11 \mathrm{ft}$. below grade and is embedded about 6 ft. into rock (see Exhibit IV-3). A removable cover slab arrangement provides access to the vault and a weathertight roof for the vault. The two pumps are located on top of the cover slab which is bounded by $1 \mathrm{ft}$. thick reinforced concrete side walls with no roof. A shielded labyrinth is provided for access to the pumps on top of the cover slab. The vault is lined with stainless steel to a level of $6 \mathrm{ft} .8 \mathrm{in}$. above the floor providing a secondary containment capacity of approximately 5000 gallons compared to the nominal 3000 gallon tank. capacity.

The modification to Building 3092 also includes the new valve box No. $2 B$ to house valves associated with the new transfer line from the new tank vault. The valve box is a reinforced concrete box-type structure with interior plan dimensions $4 \mathrm{ft}$. by $5 \mathrm{ft}$. by $7 \mathrm{ft}$. $6 \mathrm{in}$. high. The valve box is embedded approximateiy $9 \mathrm{ft}$. below grade and has a removable 18 inch thick (for shielding) reinforced concrete cover slab. A stainless steel lıner with a capacity of 300 gallons is provided on the lower inside surface of the valve box. 
The use of the American Concrete Institute codes and standards for design and construction of the secondary containment concrete structures has been evaluated. Use of these codes and standards will assure high quality concrete structures consistent with the function of housing containment tanks and piping containing liquid process solutions.

The loads and load combinations required by the Standard Building Code. ANSI A58.1, and UCRL 15910 are appropriate for the design of the concrete structures.

The stainless steel liner provided on internal vault and valve box surfaces functions as the leak tight secondary containment barrier. The thin liner is relatively flexible compared to the heavy, reinforced concrete vault structures backing the liner. Any minor stresses introduced into the liner through strain compatibility with the concrete structures are minor and self-limiting in nature. The primary design considerations for the liner are material selection and the installation/inspection criteria. The ASME Code Sections and ASTM standard specifications that have been used are appropriate and will result in the required quality to assure leak-tightness.

The following standards, codes, and criteria were applied to the structural design and specifications for fabrication and installation of the structural systems.

- Standard Building Code 1988

- Uniform Building Code 1988 (earthquake regulations) 
ACl 318-83 (Revised 1986), "Buiding Code Requirements for Reinforced Concrete"

ACl $301-84$ (Revised 1987), "Specifications for Structural Concrete for Buldings"

- ACI 515 1R-79 (Revised 1985), "A Guide to the Use of Waterproofing. Dampproofing, Protective, and Decorative Barrier Systems for Concrete"

ACl 117-81," Standard Tolerances for Concrete Construction and Materials"

ACl 302.1 R-80, "Guide for Concrete Floor and Slab Construction"

ACI 315-80, "Detalls and Detalling of Concrete Reinforcement"

- ACl 347,-78, "Recommended Practice for Concrete Formwork"

- ACI SP.4, "Formwork for Concrete"

- $\quad$ ACl 303R-74 (Revised 1982), "Guide to Cast-in-Place Architectural Concrete Practice"

- $\quad$ ACI 211.1-81 (Revised 1985), "Standard Practice for Selecting Proportions for Normal, Heavyweight, and Mass Concrete" 
ACl 305R-77 (Revised 1982), "Hot Weather Concreting"

ACl 306R-78 (Revised 1983), "Cold Weather Concreting"

ACl 224R-80 (Revised 1984), "Control of Crackıng in Concrete Structures"

- $\quad$ ACl 350R-83, "Concrete Sanitary Engineerıng Structures"

- American Society For Testing Materials (ASTM) Standards

The quality and testing of materiais used in the construction was addressed by reference to the appropriate ASTM standard specifications in the project specifications and by reference in project specıfications to governıng standards such as $\mathrm{ACl}$ 318 or $A C l 301$, which incorporate the applicable ASTM standard specifications.

- American Welding Society Specifications and Codes

- D1.1-88, "Structural Welding Code"

- D1.3-81, "Specification for Welding Sheet Steel in Structures"

- American Society of Mechanical Engıneers Boiler and Pressure Vessel Code, 1986, Including 1987 Addenda

- Section V. "Non-Destructive Examination" 
- Section IX, "Qualifications Standard for

Welding and Brazing Procedures, Welders, Brazers, and Welding and Brazıng Operations"

- American National Standards Institute

- $\quad$ ANSI A58.1-1982, "Minımum Desıgn Loads for Buldings and Other Struc:ures"

- Occupational Safety and Health Administration (OSHA) Regulations

- DOE Order 6430.1A, "General Design Criteria"

- UCRL 15910, "Design and Evaluation Guidelines for Department of Energy Facilities Subjected to Natural Phenomena Hazards," May, 1989 (Drait)

- Concrete Reinforang Steel Institute MSP-1-86, "Manual of Standard Practice," 24th Edition

(iii) Civil/Geotechnical Design Standards

The scope of civil/geotechnical engineering and design includes establishing plans and profiles for the underground double wall piping, the design and specification of final surface contours, backfill and paving, and the characterization of site soll properties for interfacing with foundation design.

The following listing presents standards, codes, and criteria that governed the civil and geotechnical engineering and design for the Bethel Valley LLW Upgrade Project. These standards, codes, and criteria provide a conservative basis for design and installation

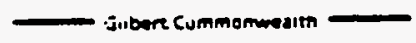

$-21$. 
of the tank system, and provide assurance that loadings and stresses imposed upon the tank vault and the double wall buried piping will not cause collapse. rupture, or fallure of these design features.

- ORNLIMMESiUSDOE "Design Criteria for the Bethel Valley Liquid Low Level Waste Collection and Transfer System Upgrade Project," Issued approved September, 1988

- Subsurface soil and rock conditions and the groundwater level are based on information obtained from the following sources.

- Logs of borings No. 25 through 29, 31 through 35,37 through 40, and 111 drilled in 1988.

- Information on borings PB-6, PB-8, PB-10, SB-7 and SB-8 drilled during Conceptual Phase Drilling Program, provided by MMES (D. C. Haberkost) through letter dated September 8, 1988.

- Rock surface data on Union Carbide Nuclear Corporation drawings number D36313 and D36314.

- Laboratory soll test data in EDGe repor tItled "Proposed Bethel Valley Low Level Waste Project," dated June 22, 1988.

- MMES Technical Specifications and Sample Specifications

- MMES Engineering Standards 
- UCRL-15910, "Design and Evaluation Guidelines for Deparment of Energy Facilities Subjected to Natural Phenomena Hazards," draft dated May. 1989, for maximum ground acceleration at ground surface $(=0.32 \mathrm{~g}$ ) for underground LLW transfer pipelines and tank vault

- ERC'EDGe Report, "PIpe 8ackfill Testing, Oak Ridge Reservation, Oak Ridge, Tennessee," dated June 28,1990

- DOE General Design Criteria (DOE 6430.1A) for design basis earthquake dynamic analysıs

- UCRL-53582, Rev. 1, "Natural Phenomena Hazards Modeling Project: Seismic Hazard Models for Department of Energy Sites," dated November, 1984

- Civil/Geotechnical Construction/Installation Standards (i.e., Interface Procedures):

- Tennessee Department of Transportation "Standard Specifications for Road and Bridge Construction," March 1, 1981, with revisions and additions

- U.S. Department of Labor, Occupational Safety and Health Administration (OSHA) Standards, 29CFR 1926/1910, 1987

AASHTO T180-831, "Moisture-Density Relations of Sorls Using a $10 \mathrm{lb} .(4.54 \mathrm{~kg})$ Rammer and an 18-in. (457 mm) Drop" AASHTO T191-831, "Density of Soll In-Place by the Sand-Cone Method" 
AASHTO T204-64 (1974), "Density of Soil

In-Place by the Drive Cylinder Method"

AASHTO T205-831, Density of Soil In-Place by the Rubber-Balloon Method"

AASHTO T233-70, "Density of Soll In-Place by Block, Chunk, or Core Sampling"

AASHTO T238-79, "Density of Soll and SollAggregate In-Place by Nuclear Methods (Shallow Depth)"

AASHTO T255-83. "Total Moisture Content of Aggregate by Drying"

USDOE "Determination of Inorganic Anions in Aqueous and Solid Samples by Ion Chromatography", test method, latest approved version

(iv) Instruments and Controls Engineering and Design

The codes and standards listed below cover selected aspects of the instruments and controls scope of work for the Building 3092 portion of the Bethel Valley LLW Upgrade. These codes and standards are appropriate and adequate to govern the design and installation of design features necessary for compliance with 40CFR264, Subpart. These design features comprise the level detection and leak detection provisions for the LLW tank, secondary containment vauit sumps, and the annular spaces in buried double wall pipıng. 


\section{Codes}

National Fire Protection Association (NFPA)

- NFPA 70-1990, National Electric Code (NEC)

American Welding Society (AWS)

- D1.3.81, Structural We!ding Code - Sheet Steel

- $\quad$ 1.1.88, Structural Welding Code

\section{Standards}

American National Standards Institute (ANSI)

- B16.1 1-80, Fittings, Socket-Welded, and Threaded

- B31.3-87. Chemical Plant and Petroleum Refinery Piping

- C2, National Electrical Safety Code

Instrument Society of America (1SA)

- ISA-55.1-1984, Instrumentation Symbols and Identification

- ISA-S5.4-1976 (R-81), Instrument Loop Diagrams

- ISA-RP7.1-1956, Pneumatic Control Circult Pressure Test

- ISA-S12.13-1986, Performance Requirements, Combustible Gas Detectors 
- ISA-S20-1981, Specification Forms for Process Measurement and Control Instrument

- ISA.S51.1.1979. Process instrumentation

National Electrical Manufacturer's Association (NEMA)

- 250-85, Enclosures

- 1C5-6-83, Enclosures for Industrial Controls

- 1CS-1-83, General Standards

- WC-5. Thermoplastic Insulated Wire and Cable

- WC-7, Cross-linked Thermosettıng Polyethylene Insulated Wire and Cable

- WC8, Ethylene-Propylene Rubber Insulated Wire and Cable

(v) Electrical Engineering and Design (Cathodic Corrosion Protection)

The standard listed below covers the design, installation, and testing of cathodic protection systems for buried metallic components. The use of this standard is appropriate to provide satisfactory corrosion protection for the buried double wall pipe (outer pipe in contact with soll). No tanks are directly in contact with the soil.

Certain other codes and standards that are required to assure the adequate design and installation of level and leak detection systems are listed in the Instruments and Controls Section. 
- RP.01.69, 1983, Recommended Practice - Control of External Corrosion on Underground or Submerged Metallic Piping Systems

\section{IV.B.1(b) Hazardous Substance Characteristics}

The hazardous and/or radioactive substances handled by Building 3092 and discharged to the ORNL CWCH are listed in Table B-1. This characterization is based on assessments of facility mission requirements and historical knowiedge of previous waste stream properties, and is provided by Martın Marietta Energy Systems (ORNL Management and Operations Contractor) as input to this assessment.

It is expected that the waste stream analysis presented in Table $B .1$ is representative of the process solutions to be handled by the tank in Bulding No. 3092. However, the composition of this waste stream may vary as specific experiments, analyses, and campaigns are conducted. Of principal concern for this assessment is the suitability of the material selected as the primary fluid boundary for piping exposed to unadjusted, undiluted waste. In this regard, the $\mathrm{pH}$ value as a measure of acidity and aggressiveness is of princıpal interest. The suitability of primary fluid boundary materials is discussed in IV.B. 1.(a)(i) of this assessment.

The variations in composition of the waste stream are limited by the General Waste Acceptance Criteria, which specifies activity and concentration limits for waste discharged into the LLW system. These criteria are presented below: 


\section{Waste Acceptance Criteria}

The LLW system should be used to collect and treat all solutions containing radioactivity above the levels listed in Table B-2, with the following provisions:

- Liquid radioactive wastes added to the LLW system must not have an activity concentration exceeding $5 x$ $1010 \mathrm{~Bq} / \mathrm{L}(5 \mathrm{cl} / \mathrm{gal})$.

- Solutions containing 233U, 235U, 235Pu, or 24:Pu must be mixed with depleted uranium or natural thorium so that the resultant solution will contain at least 100 parts by weight of $238 \mathrm{U}$ or $232 \mathrm{Th}$ per part by weight of the fissile isotope(s).

- Solutions containing TRU isotopes of $233 \mathrm{U}$ that are added to the LLW system must not have a total specific activity from those nuclides greater than $3.7 \times 106 \mathrm{~Bq} / \mathrm{kg}$ $(100 \mathrm{nCi} / \mathrm{g})$.

- Beta-gamma emitting waste greater than $5 \times 1010 \mathrm{~Bq} / \mathrm{L}$ ( $5 \mathrm{Ci} / \mathrm{gal}$ ) and high toxicity alpha and TRU waste greater than $3.7 \times 106 \mathrm{~Bq} / \mathrm{kg}(100 \mathrm{nCi} / \mathrm{g})$ must be diluted to levels below those limits prior to discharge.

- Before disposing of liquid waste containing reportable nuclear material, the generator must execute form UCN-6073 to request and receive permission from the Special Materials Management Department.

Reportable quantities of nuclear material are listed in Health Physics Procedure 5.3, page 7, Table 2. The generator prepares form UCN-2681 to complete the transfer of the reportable nuclear material to either the Liquid and Gaseous Waste Operations Deparment or the Solid Waste Operations Department. 
Table B-1

BETHEL VALLEY LIQUID LOW LEVEL WASTE

STREAM CHARACTERIZATIONS

BUILDING 3092 - CENTRAL OFF.GAS SCRUBBER FACILITY

3039 STACK SCRUBBER SOLUTION COMPOSITION

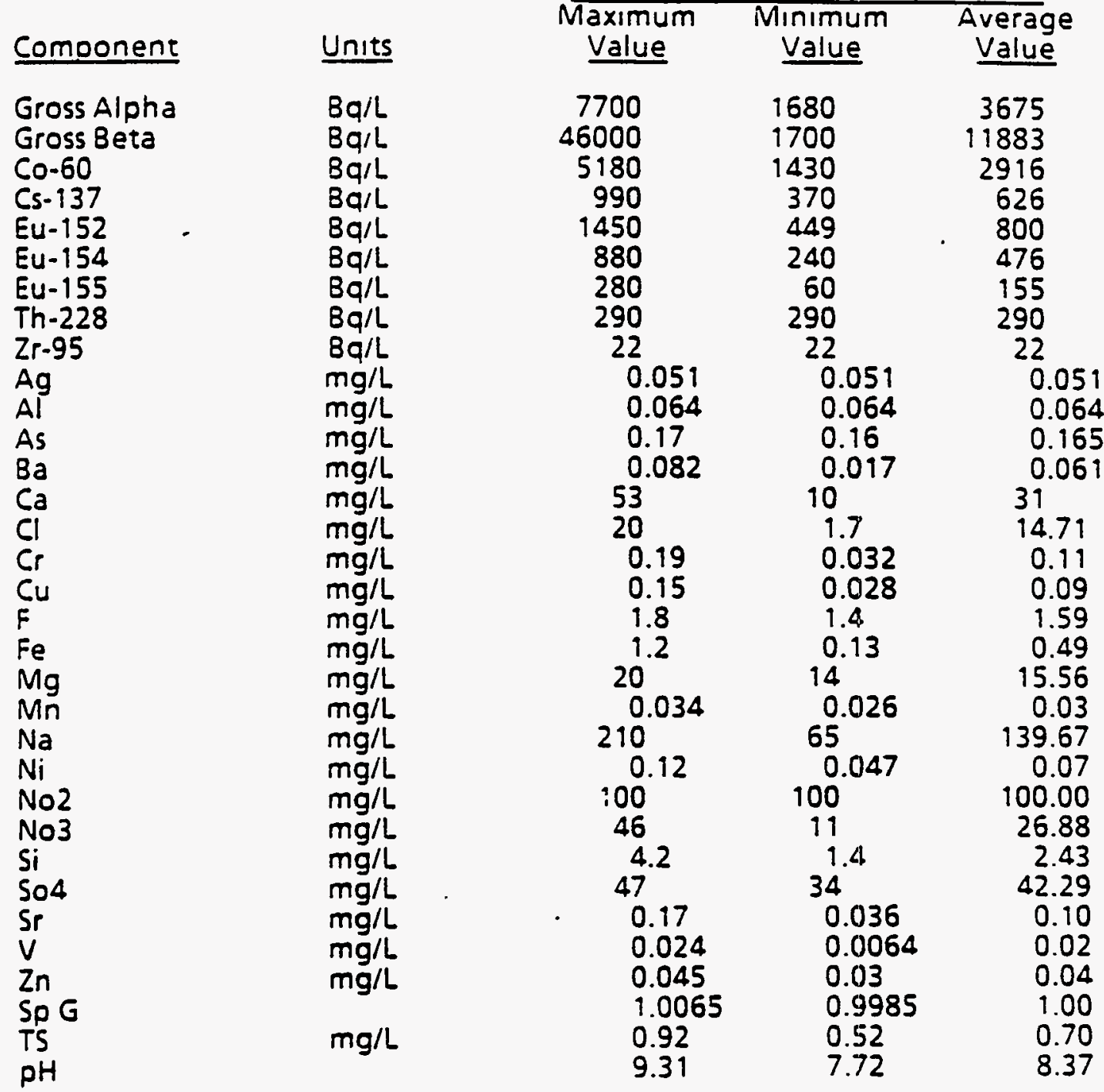


GROSS ALPHA

GROSS BETA

Sr-90

Cs-137

Co.60

Eu-152

Eu-154

Eu-155

Ru-106

ZrNb-95
$10 B q / L$ $10,0008 q / L$

10,0008qiL $4008 \mathrm{q} / \mathrm{L}$ $185 \mathrm{~Bq} /$ " $740 \mathrm{~Bq} / \mathrm{L}$ $740 \mathrm{~Bq} / \mathrm{L}^{*}$ $3700 \mathrm{~Bq} / \mathrm{L}$ * $222 \mathrm{~Bq} / \mathrm{L}$ $1,480 \mathrm{~Bq} / \mathrm{L}$

- DOE order 5400.5 DCG values

LLW, which also contains toxic materials (PCB's, mercury, etc.), should not be discharged to the LLW system (unless a waiver LS granted by Waste Management Operations), but should be transferred to the Hazardous Waste Operations Group for storage untıl its ultimate disposition is determined. Organic solvents or organic chemicals contaminated with radioactivity may be discharged into LLW drains provided the primary hazard of concern is radioactivity. Sanitary waste must not be discharged to the LLW system untess a medical emergency exists.

No new LLW streams greater than 15 gpd in volume are to be added without the permission of the Liquid Waste LCO.

\section{IV.B.1(c) Corrosion Protection}

The replacement Tank System design for the Building 3092 facility does not expose the external shell of any metal tanks to direct contact with the soil or with water. As noted previously, the scrubber recirculation tank is located in an underground, lined, concrete vault. However, a significant 
amount of buried piping constitutes an important part of the design. This buried piping is in direct contact with a backfill material selected to provide favorable design properties, as discussed in Section IV.B.4 and IV.B.6 of this assessment.

Norton Corrosion Limited. Inc., under subcontract to the Architect/Engineer, has reviewed orıgınal soil data (provided by Martin Marietta Energy Systems), engineered backfill characteristics, pertinent design drawings and specifications, and desıgn ca!culations to ensure pertinent criteria have been met. This includes providing a system that requires mınımal maintenance and meets the design criteria life requirements. The specific criteria used have been assessed with the results as follows:

\section{(i) Soil Corrosion Factors}

Soil data was reviewed and offered an adequate representation of the soll characteristics throughout the piping routes. In addition, characteristics of the piping backfill were provided and included in the design calculations. This design provides relatively controlled environmental conditions, due to the use of an engineered backfill material to be installed in a prescribed manner. This increases the confidence level in the expected performance of the entire corrosion protection system.

A review of pertinent electrical drawings was conducted to determine possible sources of potentially damaging current interference. This includes high voltage power lines, other cathodic protection systems, or dc power sources. The results of this review found no immediate concerns. It should be noted that the postinstallation testing will test for current interference. 
A number of corrosion control measures have been implemented. Specifically, the outer (secondary) containment pipe of the double wall LLW pipe system utilizes a Type 304L stainless steel alloy. In addition, a high dielectric coating will be applied to isolate the piping from the backfill and surrounding soll. Since no coating system is $100 \%$ effective, a gaivanic cathodic protection system is provided to protect any exposed metal. A review of these systems found that they are properly designed and meet all design criterı.

Electrical isolation of the piping is provided to maintain the integrity of the corrosion control systems. This includes isolation of the new piping from new and existing structures, leak monitoring equipment, and. concrete vault penetrations. The materials and methods used include flange isolation kits and non-metallic grounding cells provided at all isolation flanges to prevent hazardous shorting conditions from developing.

In order to test and confirm the proper operation of the cathodic protection system following installation, a number of test stations are provided. These test stations utilize copper-copper sulfate reference electrodes, which provide a reference for the measurement of electric potentials between the pipe and the soll (backfill). The performance of the cathodic protection system shall be checked and documented after installation by an N.A.C.E. certified engıneer.

Final design calculations (Ref: DC-5350-104-E01) indicate a life expectancy of 162 years, compared to the original design criteria requirement of 25 years.

Therefore, this assessment concludes that the corrosion 
protection system employed for the outer pipe of the buried double wall piping is satisfactory for its intended purpose.

\section{IV.8.1(d) Vehicular Traffic Protection}

(i) Building 3092 Tank Vault:

The edge of an existing low volume, concrete paved roadway will be approximately 14 feet in distance from the outside wall of the reinforced concrete tank vault pit. Conservatively assuming a $45^{\circ}$ zone of influence from an $\mathrm{H} 20$ truck live load (plus impact) located 14 feet from the tank vault pit wall, this load would influence the wall at a minimum depth of 14 feet by imposing a vertical surcharge load of approximately 50 psf. As the bottom of the vault walls, i.e., vault floor surface, will. be less than 10 feet below the roadway surface, no load will be imposed on the vault walls due to the vehicular traffic. However, the tank vault walls are designed for a surcharge load of 200 psf, placed uniformly over the entire ground surface at the walls. Thus, the design load exceeds the nonexistent vehicular load described above, as well as vehicular loads anticipated during construction.

(ii) LLW Underground Piping:

The radiation shielding requirernent necessitates a minimum earth cover of 3 feet above all LLW underground piping. Therefore, the piping is designed for a vertical load on the pipe equivalent to at least $\sigma$ feet of soll, which is twice the minımum earth cover. The actual soil cover on the pipe varies from approximately 3 feet to 6 feet. 
The backfill around the pipe will consist of sandbentonite mixture placed in 6-inch layers and compacted using light (hand-held) compaction equipment.

As the (outer) pipe diameter of 4 inches is small compared to the minımum 3-foot embedment and as the pipe wall will be Schedule 10 stainless steel, the pipe can be considered flexible with respect to the compact backfill around it. Also, due to the pipe flexibility and small diameter, the load imposed on it due to vehicular traffic at grade surface will be negligible. Due to light compaction equipment, the vertical load(s) imposed on the pipe will be smaller during construction than the design load. Thus, the pipe is designed conservatively with respect to vehicular or equipment loads during or after construction.

\section{IV.B.1(e) Design Considerations}

(i) The scrubber recirculation tank is housed in an underground reinforced concrete vault structure. The tank foundation consists of an $18 \mathrm{ft}$. by $8 \mathrm{ft}$. $4 \mathrm{in}$. by $1 \mathrm{ft}$. 8 in. thick reınforced concrete vault base slab.

The tank vault has the bottom of the base slab approximately 11 feet below finished grade. The base slab is founded on rock. A concrete mud mat is provided over the rock to accept the base slab. Due to the below grade embedment of the tank vault, the net maxımum bearing pressure on the rock is less than $1 \mathrm{ksf}$, well within the permissible bearing capacity of the rock. Due to the very low vault bearing pressure relative to the rock bearing capacity, settlement of the tank vault is expected to be insignificant. 
The assessment concludes that the tank foundation is conservatively designed to maintain the load of a full tank.

(ii) The scubber recirculation tank design includes the provision of anchorage for the tank to the vault structure. The anchorage has been designed for two loading conditions: seismic loading assuming the tank is full, which is the controlling seismic condition, and flotation or buoyancy forces on the tank assuming the tank is empty and the tank vault is filled with water.

Two integral supports are furnished at the bottom of the tank for vertical support. Each support rests on separate base plates that are anchored to the base slab. The base plates also function as part of the secondary containment liner. The tank is connected around the top to the adjacent vault walls. This connection is designed for lateral seismic loads and vertical buoyancy forces.

The loadings, load combinations, and permissibles comply with UCRL 15910 for the high hazard classification. The maximum horizontal ground surface acceleration used in the design is $0.32 \mathrm{~g}$, which corresponds to a hazard annual probability of exceedance of $2 \times 10.4$ for ORNL (Ref UCRL 15910, Table 4-3). Since the tank is anchored to the walls of the vauit which is embedded in rock, seismic loads for the design of the tank anchorage correspond to use of the peak value from the median centered Newmark and Hall response spectrum for a competent soil site (conservative assumption) anchored at $0.32 \mathrm{~g}$,assuming $5 \%$ equipment damping. The resulting peak horizontal acceleration is $0.68 \mathrm{~g}$. Directional components are combined by using the maximurn response in one 
direction plus $40 \%$ of the maximum from the other two directions. In addition, UCRL 15910 permits use of $80 \%$ of the motion from the second horizontal direction and $60 \%$ of the peak acceleration for the vertical direction when peak response spectra accelerations are used. The anchors are designed in compliance with $\mathrm{ACl} 349$

Appendix B, "Steel Embedments," to assure a ductile failure mode. This design has been evaluated and found to comply with the pertinent standards, UCRL 15910 and UCRL 53582.

The assessment concludes that the scrubber recirculation tank is adequately anchored to prevent flotation or dislodgement due to the potential intrusion of water into the tank vault or the occurrence of postulated seismic events.

Buried LLW piping is provided with a minimum equivalent of 3 feet of soll overburden, which provides sufficient net downward force on the 4-inch diameter pipe to preclude flotation of the LLW pipe, conservatively assuming that the pipe is buried within a saturated zone.

The buried LLW pipıng is routed flexibly to minimize the effects of building displacements and seismic soll strains that result from the propagation of compression, shear, and body waves associated with the design earthquake. The restraining effects of the compacted backfill and the beneficial effects of friction at the pipe/soil interface are considered conservatively in order to calculate the combined bending and axial stresses in buried elbows and branch connections and to demonstrate that the stress levels are withın the limits set by ANSI B31.3. 
The assessment concludes that the buried double wall piping is designed to preclude displacement or damage due to the presence of groundwater or the occurrence of seismic events.

(iii) The tank vault is embedded approximately 9 feet below finished grade and is founded on rock. The average annual frost penetration, according to the Standard Building Code, is less than 10 inches for the ORNL. Therefore, frost heave will not affect the tank vault.

Similarly, all LLW pipes are buried with a minımum equivalent of 3 feet of soil overburden over the pipe and, therefore, are also unaffected by frost.

\section{IV.B.2. Tank Systems Installation}

The procedure for handling buried double wall pipe and the scrubber recirculation tank, from the time of receipt on site, up to and including lowering of the piping into the trench and lowering the tank into the tank vault, will be reviewed by a qualified installation inspector. During fabrication and construction of the Tank System, primary inspection of welds in the tank, piping, liners, etc. will be performed by MMES AWS-Certified welding inspectors. Inspection of concrete, rebar, waterproofing, etc. will be performed by qualified MMES construction engineers.

The installation inspector will observe the installation of the piping and tank and will visually inspect the completed installation for the presence of weld breaks, punctures, scrapes of protective coatings, cracks, corrosion, or other structural damage or inadequate construction/installation. Desıgn engineers from MMES and the Architect/Engineer (Gilbert/Commonwealth, Inc.) will consult with construction engineers, MMES QA personnel, and construction personnel, and will audit installation records to confirm compliance with design provisions. 
The detection and remediation of scrapes of protective coatıngs applies to the coating provided on the outside of the secondary (outer) pipe. The procedure aimed at assuring the integrity of this coating system is based on the requirement of a visual holiday inspection just prior to lowering the pipe into the excavation. Defects will be repared and rechecked prior to final installation and backfill of the pipe.

It should be noted that due to the provision of a cathodic protection system for pipe buried in soil (engineered backfill), (see Sections $8.1(c), 87$, and $B .8$ of this assessment), the presence of smail defects in the coating system, although not desirable, will not compromise the long term integrity of the system.

The remainder of this section summarizes the measures that must be undertaken during the fabrication, installation, and testing of the Tank System prior to placing the system in service. These measures are included in the technical specifications governing the design, fabrication, and installation of the Tank System, and are presented in summary form in the following installation Assessment Summary. 
INSTALLATION ASSESSMENT SUMMARY

\begin{tabular}{|c|c|c|}
\hline $\begin{array}{c}\text { Assessment Action } \\
\text { Required }\end{array}$ & By Whom & When \\
\hline $\begin{array}{l}\text { Approve subgradel } \\
\text { bottom of excavation for } \\
\text { tank vault foundation. }\end{array}$ & $\begin{array}{l}\text { MMES } \\
\text { Construction } \\
\text { Engineer }\end{array}$ & $\begin{array}{l}\text { Prior to placing fill or } \\
\text { mud mat over subgradel } \\
\text { bottom of excavation. }\end{array}$ \\
\hline $\begin{array}{l}\text { Approve subgrades for } \\
\text { slabs, pipe, and pavements }\end{array}$ & $\begin{array}{l}\text { MMES } \\
\text { Construction } \\
\text { Engineer }\end{array}$ & $\begin{array}{l}\text { Prior to placing any fill } \\
\text { over subgrade. }\end{array}$ \\
\hline $\begin{array}{l}\text { Review results of backfill } \\
\text { density, moisture, and } \\
\text { chloride/sulfate content } \\
\text { laboratory tests. }\end{array}$ & $\begin{array}{l}\text { MMES } \\
\text { Construction } \\
\text { Engineer }\end{array}$ & $\begin{array}{l}\text { Prior to placing backfill } \\
\text { around buried pipe and } \\
\text { beneath or around below } \\
\text { grade structures. }\end{array}$ \\
\hline $\begin{array}{l}\text { Observe backfill mixing } \\
\text { and placement. }\end{array}$ & $\begin{array}{l}\text { MMES } \\
\text { Construction } \\
\text { Engineer }\end{array}$ & $\begin{array}{l}\text { During mixing and } \\
\text { placement of backfill } \\
\text { around buried pipe and } \\
\text { beneath or around below } \\
\text { grade structures. }\end{array}$ \\
\hline $\begin{array}{l}\text { Review results of in-place } \\
\text { density and moisture } \\
\text { content tests for } \\
\text { subgrades and backfills. }\end{array}$ & $\begin{array}{l}\text { MMES } \\
\text { Construction } \\
\text { Engineer }\end{array}$ & $\begin{array}{l}\text { As required and during } \\
\text { placement of fill. }\end{array}$ \\
\hline $\begin{array}{l}\text { Review certification } \\
\text { documents for concrete } \\
\text { and associated materials } \\
\text { including: cement, } \\
\text { aggregates, admixtures, } \\
\text { water, unit weight of } \\
\text { concrete, curing } \\
\text { compound, form release } \\
\text { agent, concrete sealer, } \\
\text { concrete hardener/sealer, } \\
\text { grout. }\end{array}$ & $\begin{array}{l}\text { MMES Design } \\
\text { Engineer }\end{array}$ & $\begin{array}{l}\text { Prior to initial concrete } \\
\text { production. }\end{array}$ \\
\hline $\begin{array}{l}\text { Review concrete mix } \\
\text { design test reports. }\end{array}$ & $\begin{array}{l}\text { MMES Design } \\
\text { Engineer }\end{array}$ & $\begin{array}{l}\text { Prior to initial concrete } \\
\text { production. }\end{array}$ \\
\hline $\begin{array}{l}\text { Review test results for } \\
\text { chloride content in } \\
\text { concrete. }\end{array}$ & $\begin{array}{l}\text { MMES Design } \\
\text { Engineer }\end{array}$ & $\begin{array}{l}\text { Prior to initial concrete } \\
\text { production. }\end{array}$ \\
\hline
\end{tabular}

- inbort 6 momammowen -

07.9773 .026

-39 . 
INSTALLATION ASSESSMENT SUMMARY

\begin{tabular}{|c|c|c|}
\hline $\begin{array}{l}\text { Assessment Action } \\
\text { Required }\end{array}$ & By Whom & When \\
\hline $\begin{array}{l}\text { Review concrete supplier's } \\
\text { current NRMCA } \\
\text { certification. }\end{array}$ & $\begin{array}{l}\text { MMES Design } \\
\text { Engineer }\end{array}$ & $\begin{array}{l}\text { Prior to initial concrete } \\
\text { production. }\end{array}$ \\
\hline Review batch tickets. & $\begin{array}{l}\text { MMES } \\
\text { Construction } \\
\text { Engineer }\end{array}$ & $\begin{array}{l}\text { After each day of } \\
\text { concrete placement. }\end{array}$ \\
\hline $\begin{array}{l}\text { Review concrete pre- } \\
\text { placement inspection } \\
\text { forms, and composite } \\
\text { opening and embedment } \\
\text { schedules. }\end{array}$ & $\begin{array}{l}\text { MMES } \\
\text { Construction } \\
\text { Engineer }\end{array}$ & $\begin{array}{l}\text { Prior to each concrete } \\
\text { placement. }\end{array}$ \\
\hline $\begin{array}{l}\text { Review certifications for } \\
\text { reınforcing steel material } \\
\text { and gasket material for } \\
\text { access hatches. }\end{array}$ & $\begin{array}{l}\text { MMES Design } \\
\text { Engineer }\end{array}$ & Prior to installation. \\
\hline $\begin{array}{l}\text { Inspect reinforcing steel } \\
\text { for grade, number, size, } \\
\text { spacing of bars; adequacy } \\
\text { of support ties, splices; } \\
\text { clearances to formwork, } \\
\text { subgrade, and between } \\
\text { bars; cleanliness. }\end{array}$ & $\begin{array}{l}\text { MMES } \\
\text { Construction } \\
\text { Engineer }\end{array}$ & $\begin{array}{l}\text { Prior to each concrete } \\
\text { placement. }\end{array}$ \\
\hline $\begin{array}{l}\text { Review shop detail and } \\
\text { installation drawings for } \\
\text { stainless liners, gaskets, } \\
\text { reinforcing steel, and } \\
\text { waterproofing. }\end{array}$ & $\begin{array}{l}\text { MMES Design } \\
\text { Engineer }\end{array}$ & Prior to fabrication. \\
\hline $\begin{array}{l}\text { Review qualification } \\
\text { certifications of } \\
\text { procedures and welders to } \\
\text { ASME Code Section IX } \\
\text { requirements for stainless } \\
\text { steel liners. }\end{array}$ & $\begin{array}{l}\text { MMES } \\
\text { Quality Dept. } \\
\text { (AWS } \\
\text { Qualified } \\
\text { Weld } \\
\text { Inspector) }\end{array}$ & $\begin{array}{l}\text { Prior to performance of } \\
\text { work. }\end{array}$ \\
\hline $\begin{array}{l}\text { Review installation } \\
\text { instructions for gaskets } \\
\text { and waterproofing. }\end{array}$ & $\begin{array}{l}\text { MMES Design } \\
\text { Engineer }\end{array}$ & Prior to field installation. \\
\hline $\begin{array}{l}\text { Review manufacturer } \\
\text { certification of membrane } \\
\text { waterproofing applicator. }\end{array}$ & $\begin{array}{l}\text { MMES Design } \\
\text { Engineer }\end{array}$ & $\begin{array}{l}\text { As part of acceptance of } \\
\text { proposed waterproofing } \\
\text { system. }\end{array}$ \\
\hline
\end{tabular}


INSTALLATION ASSESSMENT SUMMARY

\begin{tabular}{|c|c|c|}
\hline $\begin{array}{c}\text { Assessment Action } \\
\text { Required }\end{array}$ & By Whom & When \\
\hline $\begin{array}{l}\text { Certification of membrane } \\
\text { waterproofing adherence } \\
\text { test to concrete substrate. }\end{array}$ & $\begin{array}{l}\text { MMES Design } \\
\text { Engineer }\end{array}$ & Prior to field installation. \\
\hline $\begin{array}{l}\text { Review the results of the } \\
\text { concrete compressive } \\
\text { strength cylinder break } \\
\text { test. }\end{array}$ & $\begin{array}{l}\text { MMES } \\
\text { Construction } \\
\text { Engineer }\end{array}$ & $\begin{array}{l}\text { Within one week after } \\
\text { results are submitted. }\end{array}$ \\
\hline $\begin{array}{l}\text { Review the results of } \\
\text { slump, air content, and } \\
\text { temperature tests. }\end{array}$ & $\begin{array}{l}\text { MMES } \\
\text { Construction } \\
\text { Engineer }\end{array}$ & $\begin{array}{l}\text { Daily during concrete } \\
\text { placement. }\end{array}$ \\
\hline $\begin{array}{l}\text { Review Certified Material } \\
\text { Test Reports submitted by } \\
\text { supplier of piping } \\
\text { materials for primary and } \\
\text { secondary piping, steam } \\
\text { jet ejectors, and vault liner } \\
\text { materials. }\end{array}$ & $\begin{array}{l}\text { MMES } \\
\text { Quality Dept. } \\
\text { personnel }\end{array}$ & $\begin{array}{l}\text { Upon receipt, prior to } \\
\text { fabrication and } \\
\text { installation of piping. } \\
\text { liners, etc. }\end{array}$ \\
\hline $\begin{array}{l}\text { Review Certified Materıal } \\
\text { Test Reports submitted by } \\
\text { scrubber recirculation tank } \\
\text { vendor. }\end{array}$ & $\begin{array}{l}\text { MMES } \\
\text { Quality Dept. } \\
\text { personnel }\end{array}$ & $\begin{array}{l}\text { Prior to start of tank } \\
\text { fabrication. }\end{array}$ \\
\hline $\begin{array}{l}\text { Review piping and vault } \\
\text { liner weld examination } \\
\text { records (required per } \\
\text { Tables } 8.3-1 \text { and } 8.3-2 \text { ). }\end{array}$ & $\begin{array}{l}\text { MMES } \\
\text { Quality Dept. } \\
\text { personnel }\end{array}$ & $\begin{array}{l}\text { Ongoing during } \\
\text { installation of piping and } \\
\text { vault liners. To be } \\
\text { complete prior to } \\
\text { conducting pressure test } \\
\text { for any segment of } \\
\text { piping and prior to } \\
\text { installing tank in vault. }\end{array}$ \\
\hline $\begin{array}{l}\text { Review scrubber } \\
\text { recirculation tank weld } \\
\text { examination records (per } \\
\text { Tables } 8.3-1 \text { and } 8.3-2 \text { ). }\end{array}$ & $\begin{array}{l}\text { MMES } \\
\text { Quality Dept. } \\
\text { personnel }\end{array}$ & $\begin{array}{l}\text { Following completion of } \\
\text { tank fabrication. prior to } \\
\text { leak test. }\end{array}$ \\
\hline
\end{tabular}




\begin{tabular}{|c|c|c|}
\hline $\begin{array}{c}\text { Assessment Action } \\
\text { Required }\end{array}$ & By Whom & When \\
\hline $\begin{array}{l}\text { Review piping pressure } \\
\text { test records (refer to } \\
\text { Section IV.B.5 of this } \\
\text { assessment). }\end{array}$ & $\begin{array}{l}\text { MMES } \\
\text { Quality Dept. } \\
\text { personnel }\end{array}$ & $\begin{array}{l}\text { Following completion of } \\
\text { pressure test, prior to } \\
\text { covering pipe in pipe } \\
\text { trench or pouring } \\
\text { concrete (for embedded } \\
\text { pipe). May be } \\
\text { accomplished by segment } \\
\text { or portion of piping } \\
\text { system that can be } \\
\text { isolated. }\end{array}$ \\
\hline $\begin{array}{l}\text { Review scrubber } \\
\text { recirculation tank leak test } \\
\text { records. }\end{array}$ & $\begin{array}{l}\text { MMES } \\
\text { Quality Dept. } \\
\text { personnel }\end{array}$ & Prior to shipment. \\
\hline $\begin{array}{l}\text { Conduct final visual } \\
\text { inspection of waste pipe } \\
\text { system, scrubber } \\
\text { recirculation tank and } \\
\text { vault liner (inspect for } \\
\text { weld breaks, punctures, } \\
\text { scrapes of protective } \\
\text { coatings, cracks, corrosion, } \\
\text { or other structural } \\
\text { damage or inadequate } \\
\text { construction/installation) }\end{array}$ & $\begin{array}{l}\text { MMES } \\
\text { Quality Dept. } \\
\text { personnel }\end{array}$ & $\begin{array}{l}\text { Prior to backfill of pipe } \\
\text { segment(s) and prior to } \\
\text { lowering tank into vault } \\
\text { and installing vault } \\
\text { cover. }\end{array}$ \\
\hline $\begin{array}{l}\text { Inspection of cathodic } \\
\text { protection system for } \\
\text { buried piping - Includes } \\
\text { visual confirmation of } \\
\text { anode wire placement in } \\
\text { pipe trench, continuity } \\
\text { tests of cathodic } \\
\text { protection circuits, } \\
\text { measurement of pipe to } \\
\text { soil potentials. }\end{array}$ & $\begin{array}{l}\text { N.A.C.E. } \\
\text { qualified } \\
\text { corrosion } \\
\text { expert }\end{array}$ & $\begin{array}{l}\text { Prior to backfill of pipe } \\
\text { trench (pipe to soil } \\
\text { potential measured after } \\
\text { backfilling). }\end{array}$ \\
\hline
\end{tabular}


INSTALLATION ASSESSMENT SUMMARY

\begin{tabular}{|c|c|c|}
\hline $\begin{array}{l}\text { Assessment Action } \\
\text { Required }\end{array}$ & By Whom & When \\
\hline $\begin{array}{l}\text { Witness or review } \\
\text { documented results of } \\
\text { functional testing for Tank } \\
\text { System suppor } \\
\text { equipment, including: } \\
\text { - Level instrumentation } \\
\text { in sumps and tanks } \\
\text { - Pressure } \\
\text { instrumentation for } \\
\text { double-wall piping } \\
\text { annular space } \\
\text { - Steam jet ejector } \\
\text { capability to remove } \\
\text { liquid from sumps and } \\
\text { tanks } \\
\text { - Scrubber Recirculation } \\
\text { Pump and System } \\
\text { Functional Testing to } \\
\text { assure leak-tight } \\
\text { operation of pump } \\
\text { seals, valve stem piping } \\
\text { and piping flanges. }\end{array}$ & $\begin{array}{l}\text { MMES } \\
\text { Design } \\
\text { Engineer }\end{array}$ & $\begin{array}{l}\text { Prior to placing Tank } \\
\text { System into } \\
\text { contaminared service. }\end{array}$ \\
\hline
\end{tabular}




\section{IV.B.3. Inspection Reports}

The installation of the Building 3092 Tank System utilizes a comprehensive and stringent set of inspections to assure the leaktight integrity of the Tank System, following installation. These include inspections of shop and field welds in LLW primary and secondary piping and in the stainless steel vault liners, in accordance with Table $8.3-1$. The tank is designed and fabricated in accordance with the ASME Boiler and Pressure Vessel Code, Secion VIII, Div. 1 to the extent that it applies. This code requires qualified and documented weld examination procedures. The installation assessment will include reviews of weld examination records, leak test records, material certifications, and on-site walkdowns and visual inspections of essential portions of the Tank System.

The weld examinations noted above, in conjunction with a thorough visual examination of the entire system, provide assurance that potential weld breaks, punctures, cracks, and corrosion will be detected and remedial work undertaken prior to closure of the system, i..e, embedding in concrete, burial in fill, or installation of cover slabs. Welding inspectors shall be certified by AWS QC- 1 .

MMES will maintain a retrievable file of inspection reports, test records, and other pertinent documentation. A listing of required inspection reports follows in Table B.3-2. These reports, records, etc. will be reviewed, on a statistical sample basis, by the Installation Assessment team, to assure that acceptable welds have been produced. 
(\% ol dn) wopuey (b)

IS $M$ asnpasold SJWW II!!

ZS.M כınpasosd SJWW Ul!m әsuepsosse UI aq ol uo!leu!uexa ग!ydes6o!pey (Z)

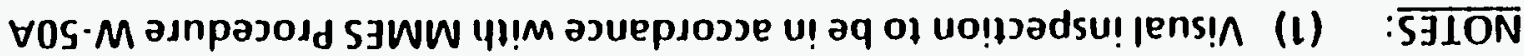

\begin{tabular}{|c|c|c|c|c|c|}
\hline$x$ & $x$ & $x$ & $x$ & \multicolumn{2}{|c|}{ 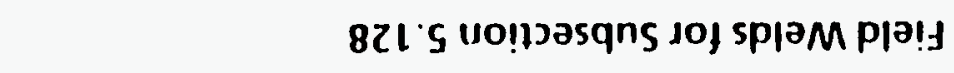 } \\
\hline$x$ & $x$ & $x$ & $x$ & 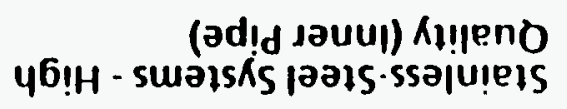 & 821 's uo!̣josqns \\
\hline$x$ & & $(b)$ & $x$ & moisরis M7t joj adid נaןno & 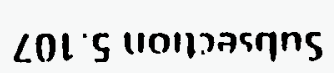 \\
\hline$x$ & & & $x$ & 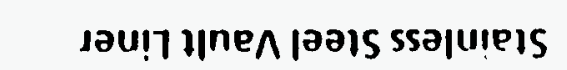 & $0 \forall \angle b$ (10Ir)asqns \\
\hline $\begin{array}{c}(\varepsilon) \\
\text { ssed } 1 \text { set } \\
\operatorname{lad} \partial \hat{K}_{0}\end{array}$ & 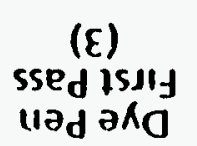 & $\begin{array}{c}(z) \\
\text { Kydes6o!pey } \\
?: n 00 i\end{array}$ & $\begin{array}{l}(1) \\
\text { jensin }\end{array}$ & ə॥!! & səqun \\
\hline
\end{tabular}

A\&甘WWחS NOIIJ3dSNI G73M

เ-E. $\mathbf{3} \exists 78 \forall \perp$ 
INSPECTION REPORT

Piping Welds

Visual Inspection

100\% Radiography

Dye Penetrants, First and Last Pass

Piping, Fittings, and Flanges (Luquid Penetrant)

Secondary Pipe

Primary Pipe

Stainless Steel

PIping (Ultrasonic)

Primary Pipe Stainless Steel

\section{SPEC. REFERENCE}

5.100, Attachment 1

5.100, Attachment 1

5.100, Attachment 1

5.107, Paragraph $2 . E$

5.128, Paragraph 2.E.2)

5.128, Paragraph 2.E.3)

Scrubber Recirculation Tank

Radiography of Welds

Tank Shell Butt Welds

9.101, Paragraph 9.A.a

Dye Penetrant Exam of Welds

Welds of Appurtenances, Lifting Lugs, Supports to Tank Shell

9.101, Paragraph 9.A.C

\section{Vault Liner Welds}

Visual Inspection

4.740, Paragraph 8A

Dye Penetrant, Last Pass

4.740, Paragraph 88 


\section{IV.B.4. Backfilling}

- Building 3092 Tank Vault:

Backfill around the reinforced concrete tank vault will be stabılized aggregate base course. This will consist of a premixed base material of crushed stone, binder material, and water, meeting the requirements of the Tennessee Department of Transportation "Standard Specifications for Road and Bridge Construction." Backfill will be placed in horizontal layers of 6 -inch thickness, maximum, and compacted to a minimum of $92 \%$ of the maximum dry density and within $2 \%$ of the optimum moisture content as determined per AASHTO T-180. The required compaction and moisture content will be verified during fill placement by means of in-place density tests per AASHTO T-191, T-205, or T-238.

Due to its dense and primarily granular nature, the backfill will have a friction angle of at least $40^{\circ}$, with some cohesion (ignored for design), rendering it unsusceptible to liquefaction during an earthquake. Also, while providing excellent compactability durıng construction, the backfill will minimize lateral pressure on the tank vault walls, compared to a backfill consisting of excavated soll. This assessment concludes that the design and specification of the backfill will ensure that the tank vault structure will be adequately supported. The installation of the backfill will be inspected to verify conformance with the project specifications.

\section{LLW Underground Piping:}

Bedding and backfill material Immediately surrounding all new pipe will be a uniform mixture of sand and $4 \%$ bentonite. The sand/bentonite mixture will be easily placed around the pipe and compact well during installation, under controlled moisture conditions. These properties facilitate the provision of a uniform bedding and backfill for the bursed piping, with desirable 
physical properties. Due to its swelling capability, the bentonite makes the mixture less permeable to water than sand.

The sand will have a maximum moisture content of $10 \%$ just prior to mixing, as determined per AASHTO T-255, and will be a silicious sand produced from crushed sandstone. The maximum levels of leachable chlorides and sulfates will be as follows, as determined by the Government per USDOE's "Determination of Inorganic Anions in Aqueous and Solid Samples by Ion Chromatograpny" test method:

$\begin{array}{lrr} & \text { Sand } & \text { Bentonite } \\ \text { Chlorides } & 10 \mathrm{ppm} & 50 \mathrm{ppm} \\ \text { Sulfates } & 100 \mathrm{ppm} & 5000 \mathrm{ppm}\end{array}$

These limits are established by USDOE to reduce the potential for pipe corrosion. They are based on past experience with other backfills surrounding existing similar piping at the site.

The sand/bentonite mixture will be carefully compacted to $91 \pm 1 \%$ of the maximum dry density, per AASHTO T-180, in layers not exceeding 6 inches in thickness. In-place density and moisture content tests will be performed per AASHTO T-191,T-204, T-205, T-233, or T-238.

This assessment concludes that the design and specification of the backfill will ensure that the buried piping will be fully and uniformly supported. The installation of the backfill will be inspected to verify conformance with the project specifications. 
IV.B.5. Testing

The pressure containing boundary of the primary and secondary piping and the scrubber recirculation tank is tested for leak tightness prior to being covered, backfilled, enclosed, or placed in service. The leak tests are either pneumatic or hydrostatic tests, conducted in accordance with applicable MMES specifications. These test requirements are noted in the Installation Assessment Summary and are summarized below:

Leak Testing Requirements

\begin{tabular}{llll} 
System/Component & Type of Test/Media & Code & Spec Reference \\
\cline { 2 - 5 } Primary Pipe & Pneumatic/Nitrogen & 831.3 & 5.410, Table 1 \\
Secondary Pipe & Pneumatic/Nitrogen & B31.3 & 5.410, Table 1 \\
Scrubber Recirc. Tank & Hydrostatic & & 9.101 , Para 9.b.3)
\end{tabular}

These test reports will be reviewed by the Installation Assessment Team to assure that leak-tight construction has been provided.

IV.B.6. Ancillary Equipment Protection

The methods implemented to properly support and protect ancillary equipment against physical damage and excessive stress due to settlement, vibration, expansion, or contraction are described herein: The methods used may be divided into three categories as applicable to buried double wall piping systems; single wall piping systems within a lined, seismically designed structure; and a tank (single wall) within a lined, seismically designed structure.

The buried double wall piping is completely surrounded by a sandbentonite mixture, with at least 3 feet of cover. The sand-bentonite mixture fills the bottom of the trench in which the piping system is routed. The relatively low moisture permeability of the mixture prevents the sand from acting as a conduit or wick to transport 
potential leakage significant distances, in the presence of groundwater. The remainder of the trench backfill consısts of either a premixed base material of crushed stone or earth.

The waste piping system above the vault cover slab has been analyzed for the various loading conditions that may apply, including: (1) potential settlement of structures at which the piping system terminates or is anchored; and (2) seismic loadings induced by the design basis seismic event. The stresses induced in the piping system (primary and secondary pipe) are within ANSI $B 31.3$ code allowable values for the applied loadings.

The single wall waste piping routed within the lined structure is supported for dead weight. Where appropriate, additional restraints are provided for lateral forces that may be induced by hydraulic conditions. Seismic restraint is not required since the pıping is contained within a lined, seismically qualıfied Secondary Containment structure equipped with a leak detection system. It should be noted that the basic design inherently provides a significant degree of seismic event resistance since most runs of piping in this category are relatively short and stiff. Also, the sersmic accelerations are modest because the vault structures are below grade and are themselves relatively rigid. (Amplification of seismic inputs due to structural response is minimal.)

The tank is welded to the vault liner, at locations reinforced by embedments. The tank specification requires that the tank and its supports be designed to withstand specified seismic loadings. The tank support flange and floor slab are designed to withstand uplift and pullout forces caused by seismic loadings.

This assessment concludes that the design has incorporated adequate provisions for the protection of ancillary equipment against physical damage and excessive stress. The installation will be assessed in accopdance with the requirements presented in the Installation Assessment Summary, Section IV.B.2 of this assessment. 
IV.8.7. Corrosion Protection

A thorough review of the pertinent drawings and specifications was performed to ensure that all corrosion protection recommendations were incorporated. In addition, all review comments were analyzed to determine if they had been adequately considered. The results of this review found that with the exception of a few minor discrepancies, which have been corrected, all comments and design recommendations have been properiy incorporated.

There are a number of procedures that are required to verify whether the cathodic protection system has been properly installed and tested. This is primarily accomplished by measuring pipe to soil potentials. This work will be performed by a qualified corrosion engineer per N.A.C.E. recommended practice 01-69, Rev. 1983, as noted in Section IV.B-2, Installation Assessment Summary.

This assessment concludes that the design incorporates an appropriate type and degree of corrosion protection for the buried pipıng. The installation of the corrosion protection system must be supervised by an independent corrosion expert who will, upon completion of the installation, provide a certification that the installation complies with the design requirements. The certification will be audited by the installation inspector as part of the installation assessment.

\section{IV.B.8 Corrosion Expert}

Norton Corrosion Limited, Inc., a firm that specializes in corrosion control, was involved in the design phase of the subject project. This work was assessed by an outside firm hired by Martin Marietta that reviewed the design calculations and provided comments. All comments were reviewed and appropriate changes made. 
Guidance to ensure the results will be implemented is found in the specifications. These require that the contractor hire a N.A.C.E. certified corrosion engineer to inspect and test the corrosion control system. It also requires submittal of all materials and qualifications for review prior to installation.

\section{IV.B.9 Documentation}

This section contains written statements by those persons required to certify the design of the Tank System and supervise the installation of the Tank System. Separate statements are provided, one covering the design of the Tank System, the other covering the installation of the Tank System (Exhibits B.9-1 and B.9-2)

The installation certification will be signed and stamped following the completion of the installation and a review of pertinent records documenting required non-destructive examinations, inspections, reparrs, and tests. These activities are described in Sections IV B 2 through and including IV.B.7 of this assessment.

Suitable retrievable permanent records of the results of the aforementioned non-destructive examinations, inspections, reparrs, and tests will be maintained by the information Services Division of Martin Marietta Energy Systems. These records will be reviewed by the person who will, in the future, certify the installation. 
This statement certifies that the replacement Tank System providing process fluid collection, storage, and $\mathrm{pH}$ adjustment, and transfer of spent process fluid to the Central Waste Collection Header for the Central Off-Gas Scrubber Facility (Building 3092) is properly designed, and the design is in accordance with the applicable requirements of 4OCFR264, Subpart J -Tank Systems, as set forth in Appendix $F$ to the Federal Facility Agreement, Docket No. 89-04-FF, covering the Oak Ridge Reservation.

This statement applies to the design of the Tank System and to the provisions specified by the design (examinations, inspections, tests) that must be executed during installation, including the conduct of any repairs that may be required during installation. A separate statement must be prepared and certified, following the installation of the Tank System, to attest that the final installation is in compliance with the design and with provisions of 40CFR264, Subpart J - Tank Systems, as presented in Appendix $F$ to the Federal Facility Agreement, Docket No. 89-04-FF.

1, the undersigned, certify that this document was prepared under my direction by qualified personnel who had complete access to pertinent design information. Based on my inquiry of those persons directly responsible for gathering and evaluating the information, the information submitted is, to the best of my knowledge and belief, true, accurate, and complete.
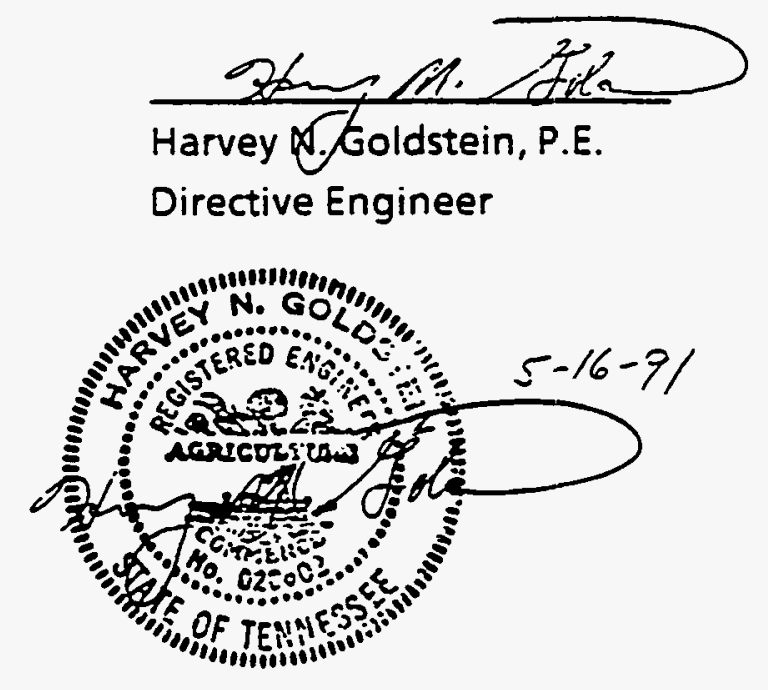

07.9773 .026

$-53-$ 
Reserved for Exhibit B.9-2 - Installation Certification

(Please note format used for Desıgn Cerificatıon) 


\section{IV.C. Standards for Containment Release Detection}

The secondary containment systems consist of an outer pipe completely enveloping the primary, inner pipe and a lined, seismically designed, reinforced concrete vault containing the scrubber recirculation tank.

The release detection system for the piping system utilizes nitrogen pressure maintaıned in the annular space between the inner and outer pipes, with continuous pressure monitoring. The release detection system for the tank system utilizes a sump at a low point in the liner/vault structure, with a level probe set in the sump to detect the presence of more than a de minimus amount of liquid.

\section{IV.C.1. Secondary Containment Systems Requirements}

\section{(a) Construction Compatibility:}

The Type 304L stainless steel secondary pipe is fully capable of containing substances that may potentially leak from the primary transfer line from the waste tank to existing valve box No. 2 (containing the tie-in to the $\mathrm{CWCH}$ ). The waste substances that are transferred via this line will have a near neutral pH and will not be chemically aggressive. The flanged connections in the waste piping, which terminate the cathodic protection for the buried portions of the system, are located within the vault structure.

The secondary containment surface material for the scrubber recirculation tank (i.e., the vault liner), which could be exposed to process fluid, assuming leakage through the primary containment, is in all cases Type 304L stainless steel material. The secondary containment is, therefore, compatible with the process streams or other substances placed in the Tank System.

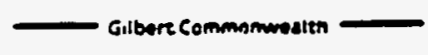


The reinforced concrete tank vault walls, base slab, and cover slabs have been conservatively designed for appropriate loadings including pressures due to surcharge, seismic, earth, and hydrostatic loadings. For purposes of design, ground water level was conservatively assumed to be 5.5 feet below grade level. The cover slabs have been designed for a minimum of 300 psflive load and have also been checked for postulated tornado missile loads associated with high hazard classification in accordance with UCRL-15910. The tornado load calculation included postulated collapse of the adjacent existıng masonry block wall surrounding the scrubber equipment area, onto the vault roof slab.

Other tornado design basis loads that were evaluated include wind pressure, atmosphere pressure change, and missiles. including a wood plank, a steel pipe, and a medium sızed automobile.

The relatively thick cover slabs provided for radiation shielding ( 24 inches equivalent over the tank vault, and 18 inches over valve box No. 2B) are conservatively adequate for all design loads. The concrete mix design incorporates entrained air to assure durable concrete with no deterioration due to freeze/thaw cycles anticipated over the service life of the vault.

Applicable American Concrete Institute Standards such as ACI 305, "Hot Weather Concreting," and $\mathrm{ACl} 306$, "Cold Weather Concreting," assure the necessary quality of concrete will be achieved under a potential range of climatic conditions during construction. In addition to the many quality requirements embodied in $\mathrm{ACl} 318$ and $\mathrm{ACl} 301$, which are specified, water content and the addition of water to the concrete are carefully controlled to minimize drying shrinkage. 
Various in-process tests, including cylinder compressive strength tests, have been required to assure consistency in the concrete mix being furnished.

\section{(b) Containment Systems Foundation}

The secondary containment system foundation consists of the $i \mathrm{ft} .8 \mathrm{in}$. thick reinforced concrete vault base slab.

The Building 3092 tank vault is a rigid reinforced concrete structure. This structure is founded on rock and is embedded approximately $5 \mathrm{ft}$. into the rock, with a 4 inch thick concrete mudmat between the rock and the bottom slab of the structure.

Due to the rigid nature of the structure and the foundation bearing on rock, the potential for bearing fallure and/or settlement are negligible. The vault structure stabllity has been checked to assure that the dead weight of the structures conservatively exceeds an assumed buoyancy force due to groundwater.

The vault base slab has been conservatively designed assuming a rigid slab model for an upward pressure corresponding to the dead plus live load of the superstructure divided by the area of the slab.

The vault walls have been designed for applicable lateral loads due to surcharge, static earth pressure, hydrostatic head of water, and lateral pressure increment due to a seismic event.

This assessment concludes that the containment systems foundation has the capability to provide support to the secondary containment system without failure and is designed for the appropriate loading conditions. 
The secondary containment system's leak detection provisions are divided into two approaches:

(i) Double Wail Piping Annulus Leak Detection

The annular spaces in the double wall pipıng systems are pressurized with nitrogen. The piping runs are divided in multiple segments, each constituting an independent pressure boundary, by division plates in the piping system.

The system configuration, for the buried double wall service lines conveying waste from Building 3092 to the CWCH at valve box No. 2, divides each run of pipe into. segments with test and monitoring stations provided at the junction between segments. Pressure monitoring for each line utilizes two pressure switches (1 out of 2 logic) serving all the buried pipe segments. If a potential leak is detected, by decrease of annular soace pressure, the leak location may be determined by acoustic monitoring or by entering the test and monitoring station and sequentially isolating segments of the buried line.

The assessment concludes that the aforementioned leak detection system for the annular space of the double wall piping system is capable of detecting virtually all leaks within consıderably less than 24 hours.

(ii) Tank Leak Detection System

The detection of leaks from the waste tank in the vault is based on the provision of a sump at the low point in the sloping tank vauit floor. Any leakage from the tank 
would flow by gravity to the sump, which is provided with a conductivity type level detection device. The tıme period required for this accumulation of liquid will vary inversely with the rate of a potential leak (i.e., the larger the leak, the shorter will be the time interval required to detect the leak).

The total quantity of a non-detected leak represents a very small fraction of the minimum rated tank capacity ( 3000 gallons), and is contained by the sump liner. which is a continuous part of the vault liner. The assessment concludes, therefore, that extremely small leaks, even if not detected within 24 hours, will be detected at the earliest practical time.

\section{(d) Drainage and Liquid Removal}

The secondary containment systems are designed to permit removal of accumulated liquids arising from leaks, spills, or condensation within the secondary containment volumetric envelope.

(i) Double Wall Piping Annulus Liquid Removal

Each individual segment of each run of double wall piping is sloped to a low point at one of its ends. A drain nipple is provided at the intermediate low points, with connecting tubing routed to a connecting point from which accumulations of liquids arising from potential leaks may be removed. The annular space drain points are accessible from one of the two test and monitoring stations provided. Leaked substances may be removed in the length of time required to detect a leak and gain access to the test and monitoring station, which consists of a standard concrete pipe section installed vertically with a weatherproof cover. 
Additional connections are provided to the annular space for venting andior injection of a flushing liquid, if required.

The as-built plan and profile of the buried piping will be reviewed during the installation assessment to assure that the design provisions for liquid removal capability are not compromised. Deviations in plan and profile during construction of the buried pipelines must have engineering approval prior to final placement of the piping.

(ii) Tank Vault Liquid Removal

The tank vault containing the scrubber recirculation tank is provided with a sloped floor and a sump of approximately 14 gallons net capacity. The sump is provided with a steam jet ejector that can pump any accumulated liquid to the process waste transfer line for conveyance to the Process Waste Treatment facility The steam jet ejector can operate to remove liquids within minutes of a decision to do so

(iii) Single Wall Piping Liquid Removal

The single wall waste piping within the confines of the Building 3092 tank vault is provided with secondary containment by the stainless steel liner of the vault. Leaking liquids are captured by the sump provided and removed by the steam jet ejector.

\section{(e) Secondary Containment for Tanks}

The secondary containment system for the scrubber recirculation tank consists of a stainless steel liner external to the tank. The liner is continuously welded so that it forms a 
leak-tight containment system for liquids. The liner is attached to the inner surface of the reinforced concrete vault. The vault structure is designed to withstand specific, defined loading conditions, as described in paragraph IV.B.1.(e) of this assessment.

The Building 3092 Tank System, therefore, is provided with two specific features, integrated into a secondary containment system, which provide a high degree of environmental protection against leaks or spills from the primary containment vessel.

\section{(f) Additional Requirements}

(i) External Liner Systems

The design of this Tank System does not utilize an external liner to achieve compliance with 40CFR264 Subpart I requirements. However, continuous water proofing is provided on the outside of the vault structures described below. The function of this waterproofing is discussed in (ii)(D)

(ii) Vault Systems

\section{(A) Capacity}

The Building 3092 tank vault is provided with a leak-tight stainless steel liner, from and including the floor of the vault, up to a height of $6 \mathrm{ft} .8 \mathrm{in}$. (nomınal) above the floor. This provides a gross volume of approximately 5,000 gallons, compared to the tank volume, at overflow, of approximately 3,300 gallons. The lined vault system, therefore, provides a margin of safety in 
capacity well in excess of the volume of the tank contained within the vault.

(8) Run-on or Infiltration Prevention

Surface water draınage will be directed around and away from the Building 3092 tank vault by means of site grading. Existing site topographic relief will prevent the build-up of surface water during storm/rainfall events. Site grades Immediately surrounding the new tank vault are maintained at lower elevations than the vault perimeter walls.

The design of the surface water drainage is combined with the characteristics of the vault subsurface design to prevent surface run.off from entering the vault. The presence of existing site fine-grained soils, combined with the dense tank vault backfill materials, will minimıze surface water infiltration as a result of precipitation. The reinforced concrete tank vault walls and the external waterproofing system also will protect the tank from run-on and infiltration effects.

The vault system has been provided with redundant design features to prevent run-on or infiltration of precipitation into the secondary containment system. Due to the constrained space at the location of the new tank vault, the tank utilizes most of the space within the tank vault. The cover slab arrangement is designed to support constructibility. A two-piece removable precast concrete cover slab design is provided immediately over the vault. A poured concrete top course is provided on top of the removable 
cover slabs to create a drainage slope to the floor drain and to provide a reliable seal agaınst infiltration of water into the secondary containment vault. A small removable concrete slab designed for shielding covers the personnel access opening into the vault. This slab is supported on a concrete curb surrounding the perimeter of the opening which prevents water from getting into the vault through the openıng. A flexible gasket is also provided under this cover slab as a redundant barrier against infiltration. This cover slab arrangement provides redundancy agaınst infiltration and also places no flexible seals in a potential direct leakage path into the vault.

The secondary containment design feature for valve box No. $2 B$ is also considered to be a vault system. Similar provisions to prevent run-on or infiltration as described above for the tank vaults were applied to valve box No. $2 \mathrm{~B}$, including proper surface drainage slope away from the valve box, a gasketed one-piece cover slab with pitched top surface, and waterproofing membrane below grade.

The reinforced concrete vault structure meets applicable requirements of $A C I 350 R$ for concrete sanitary engineering structures, including reinforcing ratios and bar spacing as well as concrete quality.

\section{(1) Water Stops}

Six-inch flexible polyvinyl chloride waterstops are provided in all construction 
joints below grade. This material is chemically resistant.

\section{(2) Coating or Lining}

The interior of the concrete vaults is provided with an impermeable coating and lining that is compatible with the stored waste and will prevent the migration of waste into the concrete. A continuous stainless steel liner is fastened to the interior surface of the vault base slab and walls. This liner provides the leak-tight barrier to contain more than $100 \%$ of the tank volume (see Paragraph IV.C. 1.(f)(ii)(A). The remainder of the interior surfaces of the tank vaults above the stainless steel liners are coated with an impermeable epoxy coating system that will prevent migration of any liquid through it into the concrete.

\section{(C) Vapor Protection}

Vapor protection is not required for the tank and vault. The tank contents, which consist of potable water with the addition of small quantities of caustic, are constantly recirculated through a contact type gas scrubber. Potentially ignitable vapors or gases, in excess of their solubility limits, would be liberated in the scrubber separator, and not accumulate in the tank or vauit. The process fluid will gradually load up with dissolved and suspended solids; periodic discharge of waste and replenishment with fresh fluid controls the solids concentrations. 
(D) Moisture Migration

The reinforced concrete vault structure has been conservatively designed for hydraulic pressure from groundwater level assumed to be 5.5 feet below grade. While groundwater levels are well below the assumed level, an impervious, continuous waterproofing has been provided. The waterproofing system consists of a standard bentonite filled panel system. This system is used for the Building 3092 tank vault because of its compatibility with the design where the lower part of the vault is embedded with concrete placed directly against the rock.

The waterproofing completely envelopes the exterior surfaces of the vault, including under the base siab and along the walls up to a level approximately 6 inches below finished grade. Finished grade around the vault is sloped to channel surface run-off away from the vault.

It is concluded that the provision of the external waterproofing system will prevent migration of moisture into the vaults.

\section{(iii) Double Walled Tanks - Not Applicable}

\section{(iv) Support Equipment}

Support equipment is provided with secondary containment that meets the requirements stated previously in this section (IV.C.) except for portions of aboveground piping that are visible for inspection on a daily basis. These piping segments are located in 
specific areas withın Building 3092 above the vault cover slab and in the vicinity of the scrubbers. Other items of support equipment and their secondary containment features are noted below.

- Buried or embedded pıping is provided with double wall construction, the outer pipe constituting the secondary boundary. Leak detection and a means of removal of accumulated leakage are provided for the annular spaces between the primary and secondary pipes.

- Steam jet ejectors, used to pump spent scrubber sorbent fluid from the scrubber recirculation tank, are housed below grade within the lined secondary containment vault. A steam jet ejector is also provided to pump fluid out of the lined vault sump. should any such fluid accumulate in the sump.

- Flanged connections used to terminate cathodic protection circuits are located in the tank vault, and therefore relies on the vault sump and level detection instrumentation. The cover slabs of the vault are equipped with a removable hatch which permits the entry of tubing to remove any accumulated liquid. A small sample may be removed for analysis prior to removal of the enture sump contents.

- Flanged connections used for tie-in of the transfer lines to the $\mathrm{CWCH}$ are located in existing valve box No. 2. The valve box is provided with a stainless steel liner and a sump (the liner is continuous and includes the sump), and an access port in the box cover slab. The access port permits sampling and removal of accumulated liquids. A leak detection 
system has not been provided as part of the scope of work for the Bethel Valley LLW Upgrade, which was limited to new valve boxes only. The Bethel Valley LLW Upgrade scope at existing valve boxes only included modifications to the piping and box structure to permit tie-in to the $\mathrm{CWCH}$. The provision of a leak detection system for existing valve boxes should be considered in future LLW upgrades.

- The desıgn of this facility does not employ sealless or magnetic coupling pumps and sealless valves that require inspection on a daily basis. However, the above grade scrubber circulating pumps and piping should be visually inspected on a dally basis to confirm that unacceptable leakage is not occurring.

- The design of this facility does not employ pressurized aboveground piping systems with automatic shut-off devices for the liquid waste.

In summary, this assessment concludes that support equipment is provided with acceptable secondary containment provisıons, including leak detection and means for removal of accumulated liquids, as applicable. 


\section{v. CONCLUSION}

This assessment concludes that the completed design for the new Tank System for the Building 3092 Central Off-Gas Scrubber Facility meets the applicable requirements of 40CFR264 Subpart J - Tank Systems, as presented in Appendix $F$ to the Federal Facility Agreement, Docket No. 89-04-FF.

- The scrubber recirculation tank and primary (inner) piping are specified to the appropriate codes and with the appropriate materials to provide satisfactory longevity in the intended service. The specifications require appropriate materials properties, weld examination and inspection, testing, and final visual inspections to assure leak tight integrity.

- Secondary contaınment features are provided where required for the scrubber recirculation tank and buried or embedded piping. Leak detection and means of removing accumulated liquids are provided within the scope of the design. The vault structures have been designed for the applicable loadings and load combinations for high hazard category structures, in accordance with UCRL 15910, including loadings assoclated with postulated seismic and tornado occurrences. A stainless steel liner has been provided in the vaults as the secondary containment barrier. Appropriate materials, fabrication and installation technıques, examinations and inspections have been specified to assure that the required quality and integrity of the design is achieved during construction.

- The buried piping is provided with a corrosion control system that projects a useful life span well in excess of the planned operational life of the system ( 162 years versus 25 years). Overall the corrosion control designs offer a very conservative approach and meet all criteria listed. The main concern with any cathodic protection system, but especially a galvanic system, is to maintain electrical isolation from all foreign structures. This has been accomplished throughout the design phase and is incorporated in the testing procedures to assure that isolation is maintained following installation. 
- The civil and geotechnical engineering design provides a satisfactory approach to the overall integrity of the Tank System and is based upon site, subsurface, and pipe backfill data provided by the Government to the Architect/Engineer. Project construction drawings and technical specifications provide requirements, tests, and approvals necessary to assure a successful installation.

- Support equipment is protected against physical damage and excessive stress due to vibration, settlement, and expansion or contraction. Secondary containment is provided for ancillary equipment, meeting the same standards as for the scrubber recirculation tank. In addition, it is noted that provision of leak detection for existing valve box No. 2 was not within the scope of work for the Bethel Valley LLW Upgrade. Future upgrades should consider provision of leak detection for this and other existing valve boxes, as may be required.

The installation assessment, to be performed during installation and prior to commissioning of the system, is to confirm that design provisions have been correctly implemented. The Installation Assessment Tearn will review pertınent test and inspection records, and perform visual inspections, walkdowns, and witness functional tests to achieve this objective. An installation certification is to be prepared and inserted in Section IV.B. 9 of this document. 
Appendix A

Central Off-Gas Scrubber Facility-Building 3092 



\section{BUILDING 3092 INTERNAL PIPING}

Drawing

Number

C3E-20013-A067

C3E-20452-A002

C3E-20452-A004

C3E-20452-A005

C3E-20452-A006

C3E-20452-A007

A3E-20452-B004

E3E-20013-D039

E3E-20013-D042

E3E-20452-D001

E3E-20452-D002

E3E-20452-D012

E3E-20452-D013

E3E-20452-D014

E3E-20452-D015

I3B-20452-0001

I3B-20452-0002

I3B-20452-0003

I3B-20452-0004

I3B-20452-0005

I3B-20452-0006

I3B-20452-0007

I3B-20452-0008

I3B-20452-0009

I3B-20452-0010

I3B-20452-0011

I3B-20452-0012

I3B-20452-0013

13B-20452-0014

I3B-20452-0015

I3B-20452-0016

I3B-20452-0017

I3B-20452-0018

I3B-20452-0019

I3B-20452-0020

I3B-20452-0021

I3B-20452-0022

I3B-20452-0023

I3B-20452-0024

I3B-20452-0025

I3B-20452-0026

I3B-20452-0027

I3B-20452-0028

I3B-20452-0029

13E-20452-0001

13E-20452-0002
Revision

0

0

0

0

0

0

0

0

0

0

0

0

0

0 (2) 0

0 (1) (a)

\author{
Title \\ Civil \\ Transfer line "E" - East Plan and Profile \\ Internal Piping Locality Map \\ Internal Piping Construction and Operation Areas \\ Internal Piping Site/Yard Piping Plan \& Sections \\ Internal Piping Civil Details, Legend and Gen. Notes \\ Internal Piping Drawing Index - Cover Sheet
}

Architectural

Building and Equip Arrangement Plans and Sections

Electrical

Cathodic Protection Sections and Details

Cathodic Protection Layout Transfer Line Piping

Conduit Layout Plan

Cable List

One Line, Schematic Diagrams and Panel Diagram

Lighting Layout Plan, Sections, Note and Layout

Cable List

Grounding Layout Plan, Sections, Note \& Legend

$$
\text { Instrumentation }
$$

Central Off-Gas Scrubber Instrument Tabulation

Loop Diagram - Recirculation Tank Level LE-9201

Loop Diagram - Recirculation Tank Level LE-9928

Loop Diagram - Annulus Discharge Pressure PT-9250

Loop Diagram - Recirculation Tank Pressure PDT-9247

Loop Diagram - Recirc. Tank Vault Comb. Gas AE-9229

Loop Diagram - Valve Box 2B

Loop Diagram - Valve Box 2B Leak Detection LE-9260

Loop Diagram - Recirc. Tank Vault Sump Level LE-9259

Loop Diagram - Recirc. Tank Discharge Temp. TE-9242

Loop Diagram - Recirc. Tank Discharge Temp. TE-9240

Loop Diagram - Recirc. Tk. Sump Dis. Temp. TE-9241

Loop Diagram - Turbine Steam Pressure PSL-9207

Loop Diagram - J-801 Pump Discharge Pressure PSL-9208

Loop Diagram - Recirc Tank Pump Dis. Press. PT-9210

Loop Diagram - Recirculation Tank PH AE-9212

Loop Diagram - Annulus Pressure Dis. Pipe PSL-9251

Loop Diagram - Air Header Pressure PT-9261

Loop Diagram - Water Header Pressure PT-9261

Loop Diagram - Ejector Steam Header Pressure PT-9255

Loop Diagram - Vault Sump Dis. Ej. Steam Valve ROV-9240

Loop Diagram - Tank Dis. EJ. Steam Valve ROV-9244

Loop Diagram - Turbine Steam Supple Valve ROV-9243.

Loop Diagram - Tank Water Supply Valve ROV-9236

Loop Diagram - Tank Dischg. Eject. Steam Valve ROV-9239

Loop Diagram - J-801 Pump Status

Loop Diagram - Vault Sump Disch. Isolat. Valve HV-9241

Loop Diagram - Tank Dischg. Isolation Valve HV-9242

Loop Diagram - Tank Dischg. Isolation Valve HV-9246

P\&ID - Steam Distribution System

P\&ID - Potable/Process Water System 
BUILDING 3092 INTERNAL PIPING (continued)

Drawing

Number

I3E-20452-0003

I3E-20452-0004

I3E-20452-0005

I3E-20452-0006

I3E-20452-0007

I3E-20452-0008

I3E-20452-0009

I3E-20452-0010

I3E-20452-0011

I3E-20452-0012

I3E-20452-0013

I3E-20452-0014

P3E-20013-C214

P3E-20013-C215

P3E-20013-C222

P3E-20452-C011

P3E-20452-C014

P3E-20452-C015

P3E-20452-C016

P3E-20452-C017

P3E-20452-C018

P3E-20452-C019

P3E-20452-C020

P3E-20452-C021

P3E-20452-C022

P3E-20452-C023

P3E-20452-C024

P3E-20452-C025

P3E-20452-SK01

P3E-20452-SK.02

P3E-20452-SK03

P3E-20452-SK04

P3E-20452-SK05

P3E-20452-SK06

P3E-20452-SK07

S3E-20013-B001

S3E-20452-B001

S3E-20452-B002

S3E-20452-B003

S3E-20452-B004 $\underline{\text { Revision }}$

0

0

0

0

0

0

0

0

0

0

0

0

0

0

0
Title

Instrumentation

P\&ID - Compressed Air Distribution System

P\&ID - Process Waste System

Instrument Location

Instrument Air Diagram

Assembly Panel K921, Side "A"

Assembly Panel K921, Side "D" - Cutout \& Drilling Dets.

Installation Details, Panel K922

Instrument Installation

Instrument Installation

Panel K921 - Wiring Diagram Side "E"

Panel K921 - Wiring Diagram Side " $A$ " Upper Half

Panel K921 - Wiring Diagram Side "A" Upper Half

Piping

External Piping for Central Off-Gas Scrubbers - Piping System Transfer Line to Valve Box 2 - Sheet 1

External Piping for Central Off-Gas Scrubbers - Piping System Transfer Line to Valve Box 2 - Sheet 2

Valve Stem Extensions - Valve boxes 2 and $2 A$

Steam Distribution System

Potable/Process Water and Caustic System

Off-Gas \& Cell Ventilation Scrubber Process

Piping System - Plan \& Sections

Piping System - Sections \& Details Sheet 1

Piping System - Sections \& Details Sheet 2

Piping System - Sections \& Details Sheet 3

Piping Details - Caustic Tank F-802

Piping Details - Valve Stem Extensions

Pipe Support Details

Pipe Support Details

Pipe Support - Description and Locations

Pipe Support Locations

Demolition - Scrubber Process Piping

Demolition - Scrubber Process Piping

Demolition - Scrubber Process Piping

Demolition - Scrubber Process Piping

Demolition - Scrubber Process Piping

Demolition - Scrubber Process Piping

Demolition - Scrubber Process Piping

Structural

External Piping for Central Off-Gas Scrubbers - Valve Box 2B Plan and Sections

Structural - Concrete, Plans and Sections

Structural - Concrete, Sects. \& Dets. - Sheet 1

Structural - Concrete, Sects. \& Dets. - Sheet 2

Structural - Concrete, Instr. \& Control Enclosure 
REFERENCE DRAWINGS:

Drawing

Number

D-36312

D-36313

D-36314

Revision

Title

Structural Plan and Details

Foundation Plan, Section \& Details

Sections and Details 


\section{DISTRIBUTION}

1. A. D. Clay

2. R. A. Dean

3-4. J. T. Etheridge

5-6. T. H. Monk

7. C. E. Mulkey

8. P. S. Wood

9. Central Research Library

10. Central ER Doc. Mgmt. Center

11. ORNL Doc. Mgmt. Center-RC

12. Laboratory Records Department

13. ORNL Patent Section

14. WMRA Document Management Center

15. Office of Assistant Manger for Energy Research and Development, DOE Oak Ridge Operations Office, P.O. Box 2001, Oak Ridge, TN 37831-8600

16. R. O. Hultgren, DOE Oak Ridge Operations Office, P.O. Box 2001, Oak Ridge, TN 37831-8541

17. C. S. Mims, DOE Oak Ridge Operations Office, P.O. Box 2001, Oak Ridge, TN 37831-8541

18. L. L. Radcliffe, DOE Oak Ridge Operations Office, P.O. Box 2001, Oak Ridge, TN 37831-8541

19. L. C. M. Roddye, DOE Oak Ridge Operations Office, P.O. Box 2001, Oak Ridge, TN 37831-8541

20-21. Office of Scientific and Technical Information, P.O. Box 62, Oak Ridge, TN 37831 